\title{
Gas, Oil, and Water Production from Grand Valley, Parachute, Rulison, and Mamm Creek Fields in the Piceance Basin, Colorado
}

Open-File Report 2010-1110 


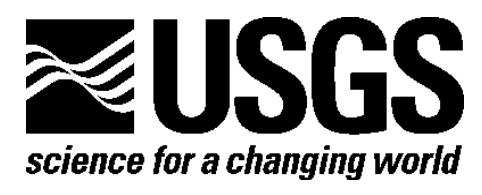

\section{Gas, Oil, and Water Production from Grand Valley, Parachute, Rulison, and Mamm Creek Fields in the Piceance Basin, Colorado}

By Philip H. Nelson and Stephen L. Santus

Open-File Report 2010-1110

U.S. Department of the Interior U.S. Geological Survey 


\section{U.S. Department of the Interior \\ KEN SALAZAR, Secretary}

\section{U.S. Geological Survey \\ Marcia K. McNutt, Director}

U.S. Geological Survey, Reston, Virginia 2010

For product and ordering information:

World Wide Web: http://www.usgs.gov/pubprod

Telephone: 1-888-ASK-USGS

For more information on the USGS-the Federal source for science about the Earth, its natural and living resources, natural hazards, and the environment:

World Wide Web: http://www.usgs.gov

Telephone: 1-888-ASK-USGS

Suggested citation:

Nelson, P.H., and Santus, S.L., 2010, Gas, water, and oil production from Grand Valley, Parachute, Rulison, and Mamm Creek fields in the Piceance Basin, Colorado: U.S. Geological Survey Open-File Report 2010-1110, 28 p., 6 plates

Any use of trade, product, or firm names is for descriptive purposes only and does not imply endorsement by the U.S. Government.

Although this report is in the public domain, permission must be secured from the individual copyright owners to reproduce any copyrighted material contained within this report. 


\section{Contents}

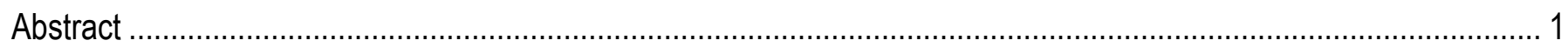

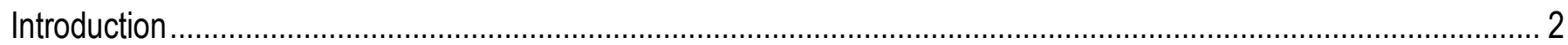

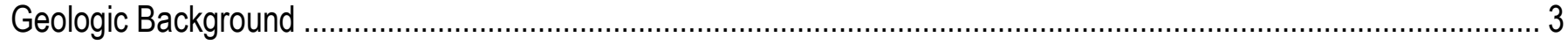

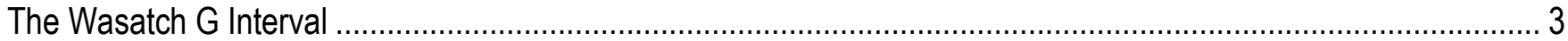

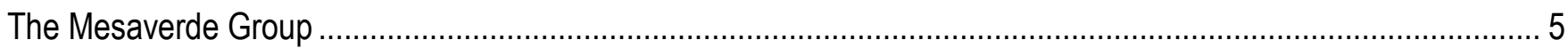

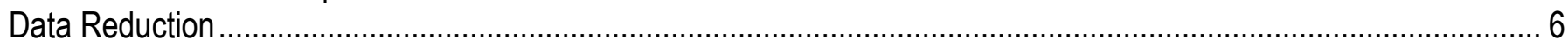

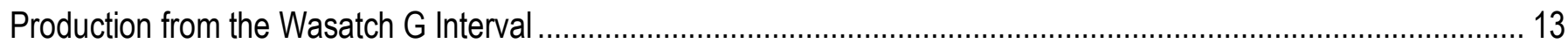

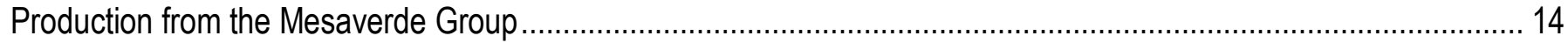

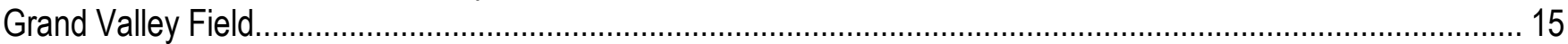

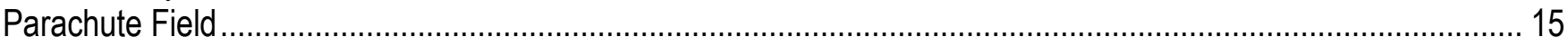

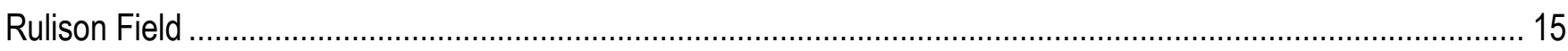

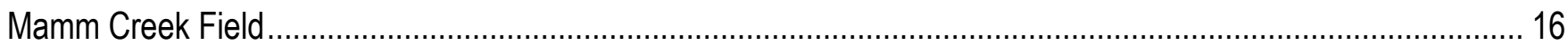

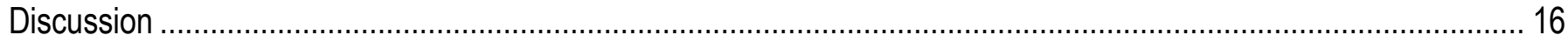

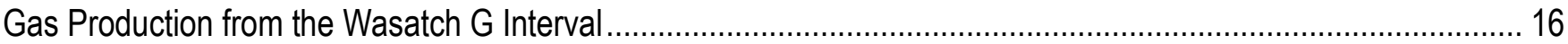

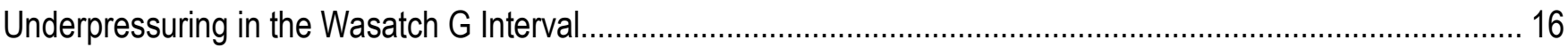

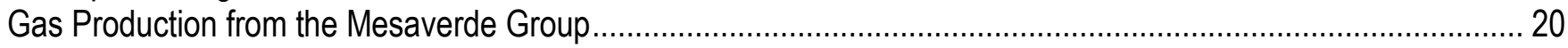

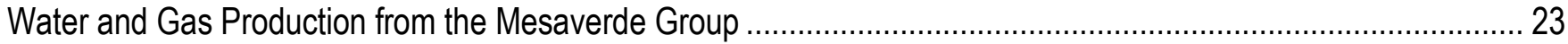

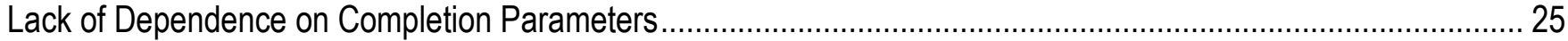

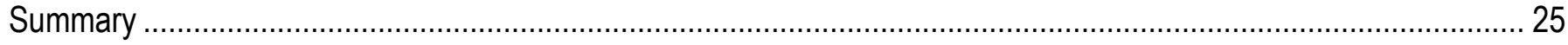

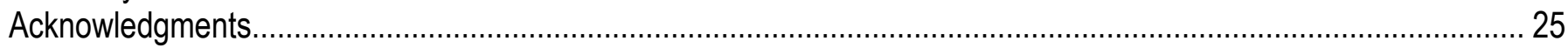

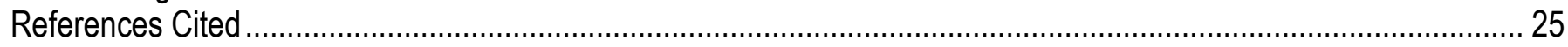

\section{Figures}

1. Map of the Grand Valley area within the Piceance Basin in western Colorado .............................................. 3

2. Stratigraphic section for the southern part of the Piceance Basin............................................................... 4

3. Cross section showing structural setting of Wasatch Formation and Mesaverde Group ...................................... 6

4. Example plot of fluid production versus time with corresponding production plots ........................................... 7

5. Example plot of fluid production versus time with plots of changes in production ............................................ 9

6. Oil and gas types plotted on a log-log diagram of oil and gas production rates.............................................. 12

7. Gas production for the Wasatch Formation and Mesaverde Group ............................................................. 17

8. Elevation of land surface and key geologic horizons in Rulison field as a function of time ................................ 18

9. Schematic diagram of Wasatch $\mathrm{G}$ interval between outcrop and gas reservoir ............................................ 21

10. Ratio of water production rate at the second sample to the first sample, plotted against the ratio of gas

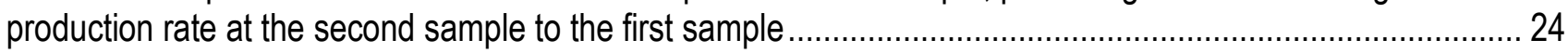

\section{Tables}

1. Estimates of water released at surface that was originally dissolved in gas in the reservoir ................................ 16

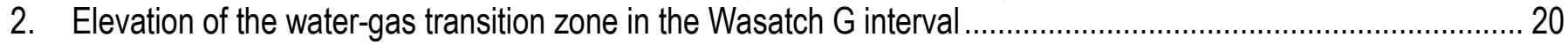

3. Ratios of gas produced at the second sample to gas produced at first sample .................................................. 22 


\section{Plates}

1. Gas and water production from the Wasatch Formation, Parachute field, Piceance Basin, Colorado .............. ink

2. Gas and water production from the Wasatch Formation, Rulison field, Piceance Basin, Colorado ...................link

3. Gas, oil, and water production from the Mesaverde Group, Grand Valley field, Piceance Basin, Colorado.

4. Gas, oil, and water production from the Mesaverde Group, Parachute field, Piceance Basin, Colorado .........link

5. Gas, oil, and water production from the Mesaverde Group, Rulison field, Piceance Basin, Colorado...............link

6. Gas, oil, and water production from the Mesaverde Group, Mamm Creek field, Piceance Basin, Colorado. link

\section{Appendixes (digital files)}

Appendix 1. Spreadsheet with well names and data for Wasatch Formation, Parachute field ..............................ink Appendix 2. Spreadsheet with well names and data for Wasatch Formation, Rulison field ................................ink Appendix 3. Spreadsheet with well names and data for Mesaverde Group, Grand Valley field ............................ink Appendix 4. Spreadsheet with well names and data for Mesaverde Group, Parachute field ...............................ink Appendix 5. Spreadsheet with well names and data for Mesaverde Group, Rulison field..................................ink Appendix 6. Spreadsheet with well names and data for Mesaverde Group, Mamm Creek field ..........................ink 


\section{Conversion Factors}

Inch/Pound to SI

\begin{tabular}{|c|c|c|}
\hline Multiply & By & To obtain \\
\hline \multicolumn{3}{|c|}{ Length } \\
\hline foot $(\mathrm{ft})$ & 0.3048 & meter $(\mathrm{m})$ \\
\hline mile (mi) & 1.609 & kilometer $(\mathrm{km})$ \\
\hline \multicolumn{3}{|c|}{ Volume } \\
\hline $\begin{array}{l}\text { barrel (bbl) (petroleum: } \\
1 \text { barrel=42 gal) }\end{array}$ & 0.1590 & cubic meter $\left(\mathrm{m}^{3}\right)$ \\
\hline cubic foot (cf) & 0.02832 & cubic meter $\left(\mathrm{m}^{3}\right)$ \\
\hline \multicolumn{3}{|c|}{ Flow rate } \\
\hline cubic foot per day (cf/d) & 0.02832 & cubic meter per day $\left(\mathrm{m}^{3} / \mathrm{d}\right)$ \\
\hline \multicolumn{3}{|c|}{ Pressure } \\
\hline atmosphere, standard (atm) & 101.3 & kilopascal (kPa) \\
\hline bar & 100 & kilopascal (kPa) \\
\hline pound per square inch $\left(\mathrm{lb} / \mathrm{in}^{2}\right)$ & 6.895 & kilopascal (kPa) \\
\hline \multicolumn{3}{|c|}{ Density } \\
\hline pound per cubic foot (lb/cf) & 16.02 & $\begin{array}{l}\text { kilogram per cubic meter } \\
\left(\mathrm{kg} / \mathrm{m}^{3}\right)\end{array}$ \\
\hline pound per cubic foot (lb/cf) & 0.01602 & $\begin{array}{l}\text { gram per cubic centimeter } \\
\left(\mathrm{g} / \mathrm{cm}^{3}\right)\end{array}$ \\
\hline
\end{tabular}

\section{Abbreviation List}

cubic feet $=\mathrm{cf}$

feet $=\mathrm{ft}$

pounds per square inch $=p s i$

pounds per square inch per foot $=\mathrm{psi} / \mathrm{ft}$

microdarcies $=\mu \mathrm{d}$

$\mathrm{mcf} /$ day $=$ thousand cubic feet per day

$\mathrm{bbl} /$ day $=$ barrels per day

$\mathrm{scf} / \mathrm{bbl}=$ standard cubic feet per barrel

$\mathrm{bbl} / \mathrm{mmcf}=$ barrels per million cubic feet

$\mathrm{lb} / \mathrm{mmscf}=$ pounds per million standard cubic feet

$\mathrm{cf} / \mathrm{mmscf}=$ cubic feet per million standard cubic feet

$\mathrm{mcf} / \mathrm{day}=$ thousand cubic feet per day 


\title{
Gas, Oil, and Water Production from Grand Valley, Parachute, Rulison, and Mamm Creek Fields in the Piceance Basin, Colorado
}

\author{
By Philip H. Nelson and Stephen L. Santus ${ }^{1}$
}

\begin{abstract}
Gas, oil, and water production data for tight gas reservoirs were compiled from selected wells in western Colorado. These reservoir rocks - the relatively shallow Paleogene Wasatch G sandstone interval in the Parachute and Rulison fields and fluvial sandstones in the deeper Upper Cretaceous Mesaverde Group in the Grand Valley, Parachute, Rulison, and Mamm Creek fields - are characterized by low permeability, low porosity, and the presence of clay minerals in pore space. Production from each well is represented by two samples spaced five years apart, the first sample typically taken two years after production commenced, which was generally in the 1990s. For each producing interval, summary diagrams of oil-versus-gas and water-versus-gas production show fluid production rates, the change in rates during five years, the water-gas and oil-gas ratios, and the fluid type. These diagrams permit well-to-well and field-to-field comparisons. Fields producing water at low rates (water dissolved in gas in the reservoir) can be distinguished from fields producing water at moderate or high rates, and the water-gas ratios are quantified.

Dry gas is produced from the Wasatch $\mathrm{G}$ interval and wet gas is produced from the Mesaverde Group. Production from the Wasatch $\mathrm{G}$ interval is also almost completely free of water, but water production commences with gas production in wells producing from the Mesaverde Group - all of these wells have water-gas ratios exceeding the amount that could exist dissolved in gas at reservoir temperature and pressure. The lack of produced water from the Wasatch $\mathrm{G}$ interval is attributed to expansion of the gas accumulation with uplift and erosion. The reported underpressure of the Wasatch $\mathrm{G}$ interval is here attributed to hydraulic connection to the atmosphere by outcrops in the Colorado River valley at an elevation lower than that of the gas fields.

The amount of reduction of gas production over the five-year time span between the first and second samples is roughly one-half, with median values of second-sample to first-sample gasproduction ratios ranging from 0.40 for Rulison-Mesaverde to 0.63 for Rulison-Wasatch G. Commencing with the first sample, the logarithm-of-production rate appears to decline linearly with time in many wells. However, water production is much more erratic as a function of time from an individual well and also from one well to the next within a field. Water production can either decrease or increase with time (from the first to the second sample). In this study, slightly more than half the wells producing from the Mesaverde Group show decreases in water production with time. Plots of water decline versus gas decline show little relation between the two, with only the wells in Rulison field displaying some tendency for water and gas to decline proportionately.
\end{abstract}

\footnotetext{
${ }^{1}$ Student at Metropolitan State College of Denver, Colo.
} 


\section{Introduction}

Tight gas sandstones are now an important contributor to gas production in the United States. Despite this importance, many questions remain concerning the nature of fluids in tight (low permeability) gas systems. This study is part of an ongoing effort to examine the early fluid production from a number of tight gas systems in the Rocky Mountain region of the United States (Nelson and Hoffman, 2009; Nelson and others, 2009a, b). Early production, rather than cumulative production, is examined in order to gain a record of fluid flow while minimizing perturbations from well interference and pressure reduction. By conducting a systematic study of a number of tight gas systems, we hope to gain insight into the fluid-flow characteristics of reservoirs and ultimately relate those characteristics to the geological setting and hydrocarbon-charging scenario. The purpose of this report is to document our findings for gas, water, and oil production from four fields in the Piceance Basin in western Colorado (fig. 1).

The ability to determine productive zones and the efficacy of completion techniques vary among operators at any given time, and both factors evolve with time as personnel gain experience in a field and as drilling and completion techniques improve. Thus, the amounts of gas, oil, and water extracted from a given well are dependent upon the level of petrophysical, drilling, and completion expertise applied to that well. This seems to be even more true in the case of tight gas systems than in highpermeability reservoirs because the consequences of errors and oversights are greater in lowpermeability reservoirs. The exercise conducted in the present paper is susceptible to the timedependent vagaries of evaluation and extraction technologies. Our hope is that our techniques of well selection, presentation of statistical results, and the changes in gas and water quantities over a five-year time span are sufficient to overcome some of the difficulties inherent in comparative case studies of fluid extraction from low-permeability systems. 


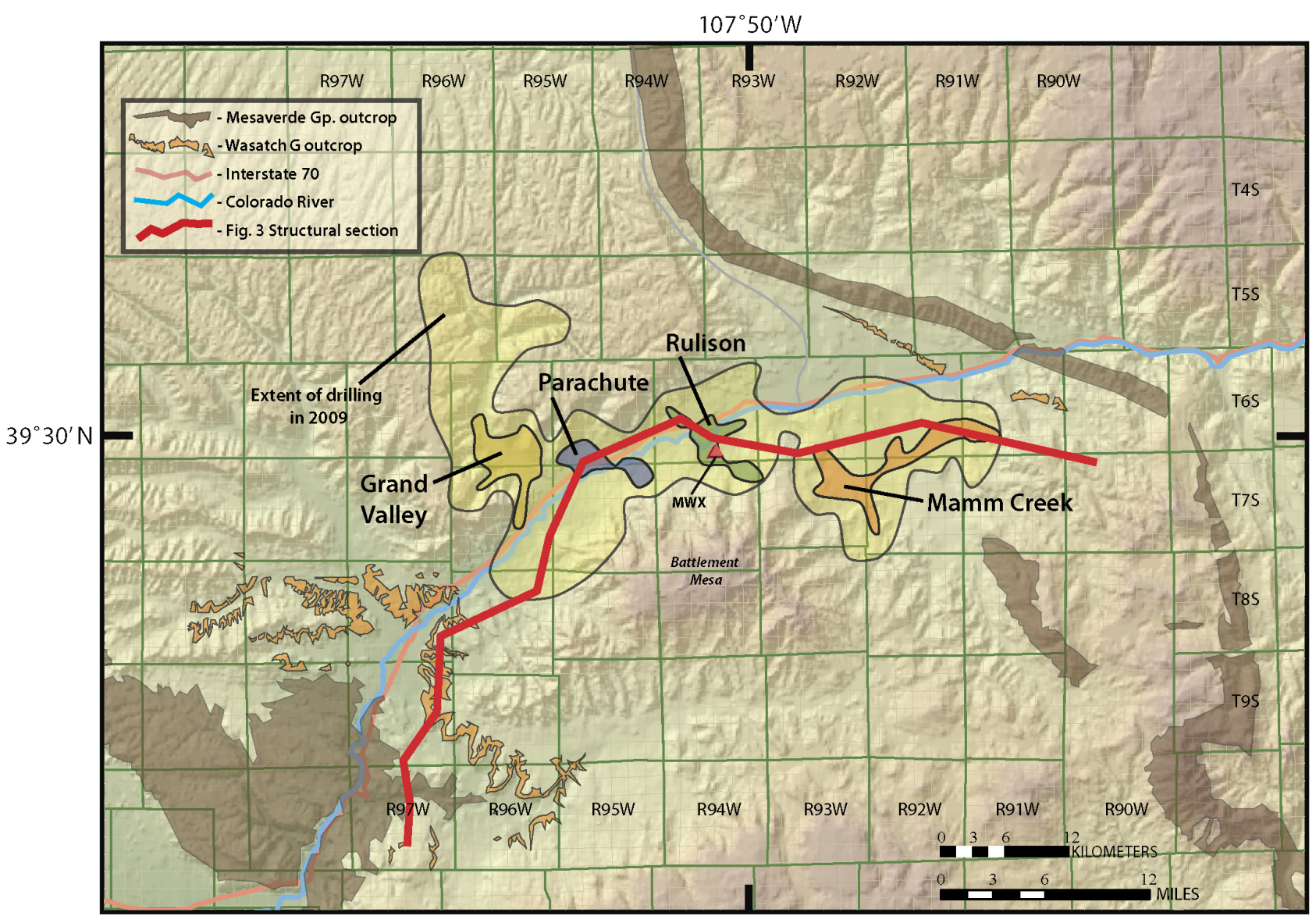

Figure 1. Map of the Grand Valley area within the Piceance Basin in western Colorado, showing outcrops of the Mesaverde Group and the $G$ sandstone of the Wasatch Formation and the locations of four gas fields. Arcuate outcrop of Mesaverde Group commencing in T.5N., R.94W. forms the eastern boundary of the Piceance Basin. Well density in these fields has increased as field development has progressed, presently forming a nearly continuous belt of wells. Extensive experimental work was conducted during the 1980s in the Mesaverde Group at the Multiwell Experimental site (MWX). [Gp., Group]

\section{Geologic Background}

\section{The Wasatch G Interval}

Gas is produced from the Tertiary Wasatch Formation in the Parachute and Rulison fields and from the Upper Cretaceous Mesaverde Group in the Grand Valley, Parachute, Rulison, and Mamm Creek fields (fig. 2). Produced fluids from both formations are considered in this report. 
Southern Part of Piceance Basin

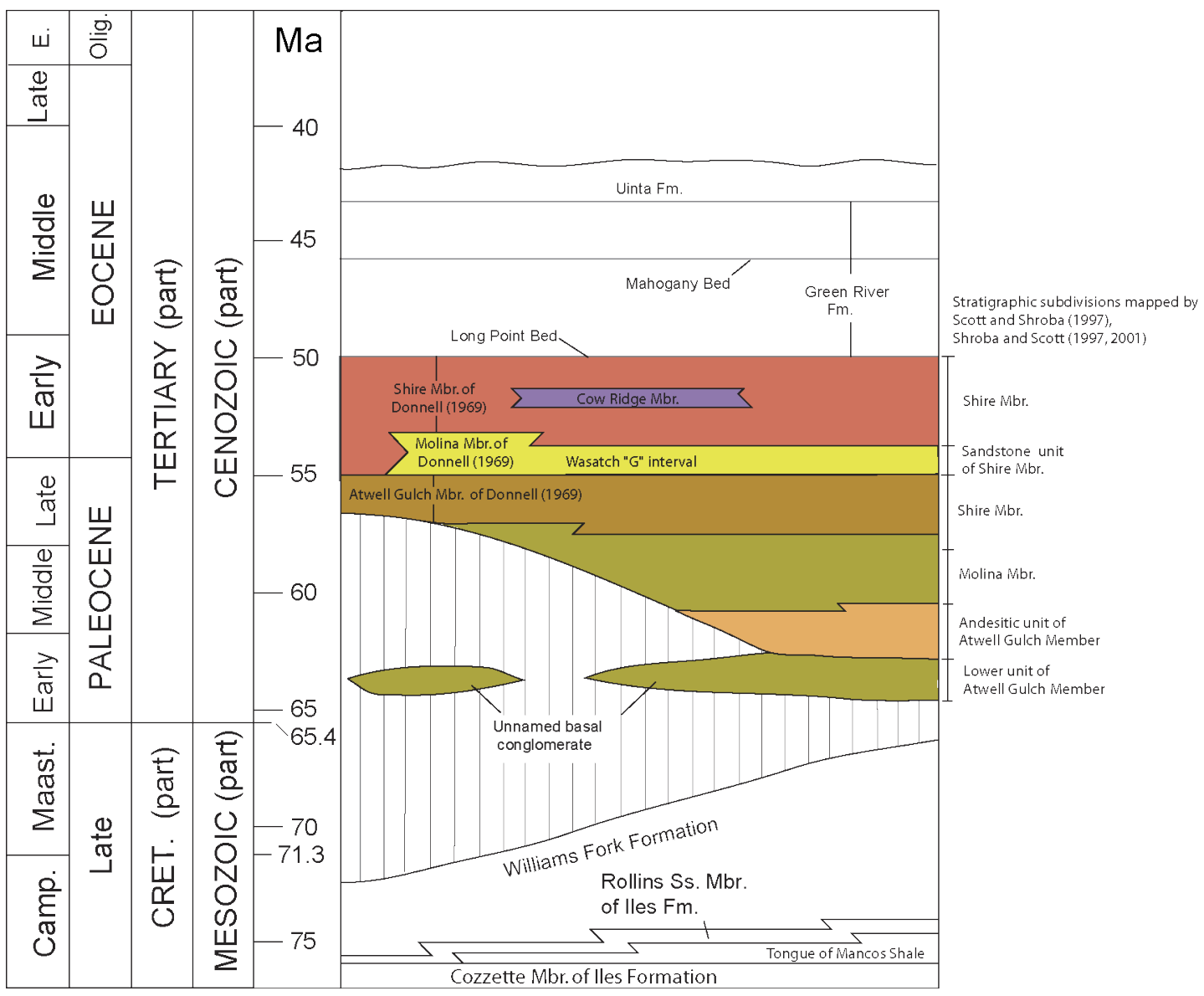

Figure 2. Stratigraphic section for the southern part of the Piceance Basin, from Johnson and Flores (2003). Note differing nomenclatures of intervals within the Wasatch Formation. Paleocene portion of Wasatch Formation is referred to as Fort Union Formation in the northern part of the basin. [Camp., Campanian; Maast., Maastrichtian; E., Olig., early Oligocene; CRET., Cretaceous; Ss., Sandstone; Mbr., Member; Fm., Formation]

The Wasatch G interval of the Wasatch Formation, referred to simply as the Wasatch G interval in this report, is late Paleocene to early Eocene in age and is a proven gas producer in the central part of the Piceance Basin (Johnson and Flores, 2003; Carlstrom, 2003). The productive area considered here lies at the southeast extremity of a northwest-trending thickening of the Wasatch $\mathrm{G}$ interval (Carlstrom, 2003, fig. 8). The Wasatch $\mathrm{G}$ interval produces a strong, continuous seismic reflector across the Parachute and Rulison fields (fig. 16 of Cumella and Ostby, 2003). In Parachute field, the net sandstone thickness of the Wasatch $\mathrm{G}$ interval determined in 46 wells ranges from 6 to 74 feet ( $\mathrm{ft}$ ), with an average thickness of $39 \mathrm{ft}$ (Carlstrom, 2003, fig. 8).

Johnson and Flores (2003) provide a detailed discussion of the problems with correlation and nomenclature in the Wasatch Formation in the southern part of the Piceance Basin. The Wasatch G interval is considered part of the Molina Member of the Wasatch Formation, as defined in the southwest part of the basin, and is equivalent to the sandstone unit of the Shire Member of the Wasatch Formation, as defined in the southeastern part of the basin (fig. 2). Photographs (figs. 17-25 of Johnson and Flores, 2003) document the amalgamated channel sandstones of the Molina Member that crop out on the west end of Battlement Mesa and in the Colorado River valley southwest of Grand Valley field (fig. 1). 
Other photographs (figs. 26-28 of Johnson and Flores, 2003) document the fluvial character of the sandstone of the Shire Member that crops out north of Mamm Creek field in sec. 11, T. 6 S., R. 92 W. (fig. 1). Because the gas is believed to be sourced from the Mesaverde Group, the Wasatch $G$ interval was incorporated within the Mesaverde Total Petroleum System in an assessment of oil and gas potential in the Uinta and Piceance Basins (Johnson and Roberts, 2003).

Pressure-depth ratios in the Wasatch Formation are 0.36 pounds per square inch per foot (psi/ft) in Rulison field and $0.35 \mathrm{psi} / \mathrm{ft}$ in Parachute field (Hemborg, 1993). These values are less than the fresh-water gradient of $0.43 \mathrm{psi} / \mathrm{ft}$. In early drilling of Rulison field, wells were drilled with air, perforated, and hydraulically fractured, but no acid was used (Martinez and Duey, 1982). Of the wells examined in this study, all were hydraulically fractured and acid was used in stimulating half the wells. Based on core measurements, porosity is 6.5 percent and permeability ranges from 0.06 to 0.25 millidarcies (md) (Martinez and Duey, 1982), but the porosity value is probably not representative, as a value of 14 percent was used by one operator as a cutoff to determine pay (S. Cumella,Bill Barrett Corporation, written commun., 2010). Maximum depth of burial was considerably greater than presentday depths; it is estimated that $4,700 \mathrm{ft}$ of rock have been removed by uplift and erosion at the MWX site in Rulison field (Nuccio and Roberts, 2003).

\section{The Mesaverde Group}

The extent and nature of the gas-productive Mesaverde Group was described by Johnson (1989) with more detailed information revealed in subsequent publications that are based on the exploration and development drilling carried out in the 1990s (Hemborg, 2000; Cole and Cumella, 2003; Cumella and Ostby, 2003; Yurewicz and others, 2008). Johnson (1989) noted that the fluvial part of the Mesaverde, which corresponds approximately to the brown interval from the top of the Cameo zone to the top of Mesaverde in figure 3, consists almost totally of lenticular channel sandstones and finegrained flood-plain deposits. The distribution of the channel sandstones can be inspected by expanding a portion of figure 3. Thicknesses of individual sandstone bodies are several tens of feet. Based on outcrop studies, the widths of sand bodies range from 40 to 2,800 ft, with average widths of five classes of sandstone bodies all less than $900 \mathrm{ft}$ (Cole and Cumella, 2003). These restricted horizontal dimensions require dense drilling patterns to access the gas that is reservoired in the sandstone bodies. The finite lenticular shapes also pose a problem in terms of how gas was emplaced into the sandstones. Cumella and Scheevel (2008) hypothesized that gas migrated upward through microfractures that formed as the result of stress changes induced by gas pressure. Present-day overpressure is greater at the bottom of the gas system than at the top.

The tight gas sandstones of the Mesaverde Group were subject to extensive field and laboratory testing during the 1980s, as summarized by Nelson (2002) and Warpinski and Lorenz (2008). Three wells, designated MWX-1, 2, and 3, were drilled, cored, and tested in Rulison field (fig. 1). Based on core measurements, the average porosity of these sandstones is less than 10 percent. Well tests showed that effective permeabilities ranged from 10 to 50 microdarcies $(\mu \mathrm{d})$, substantially greater than the permeability measurements obtained from stressed samples, whose permeabilities were less than $3 \mu \mathrm{d}$. The inconsistency between laboratory results and well tests indicated that natural fractures play a highly important role in fluid flow. Well testing also showed permeability to be strongly directional, consistent with the concept that natural fractures play a prominent role in fluid flow. 


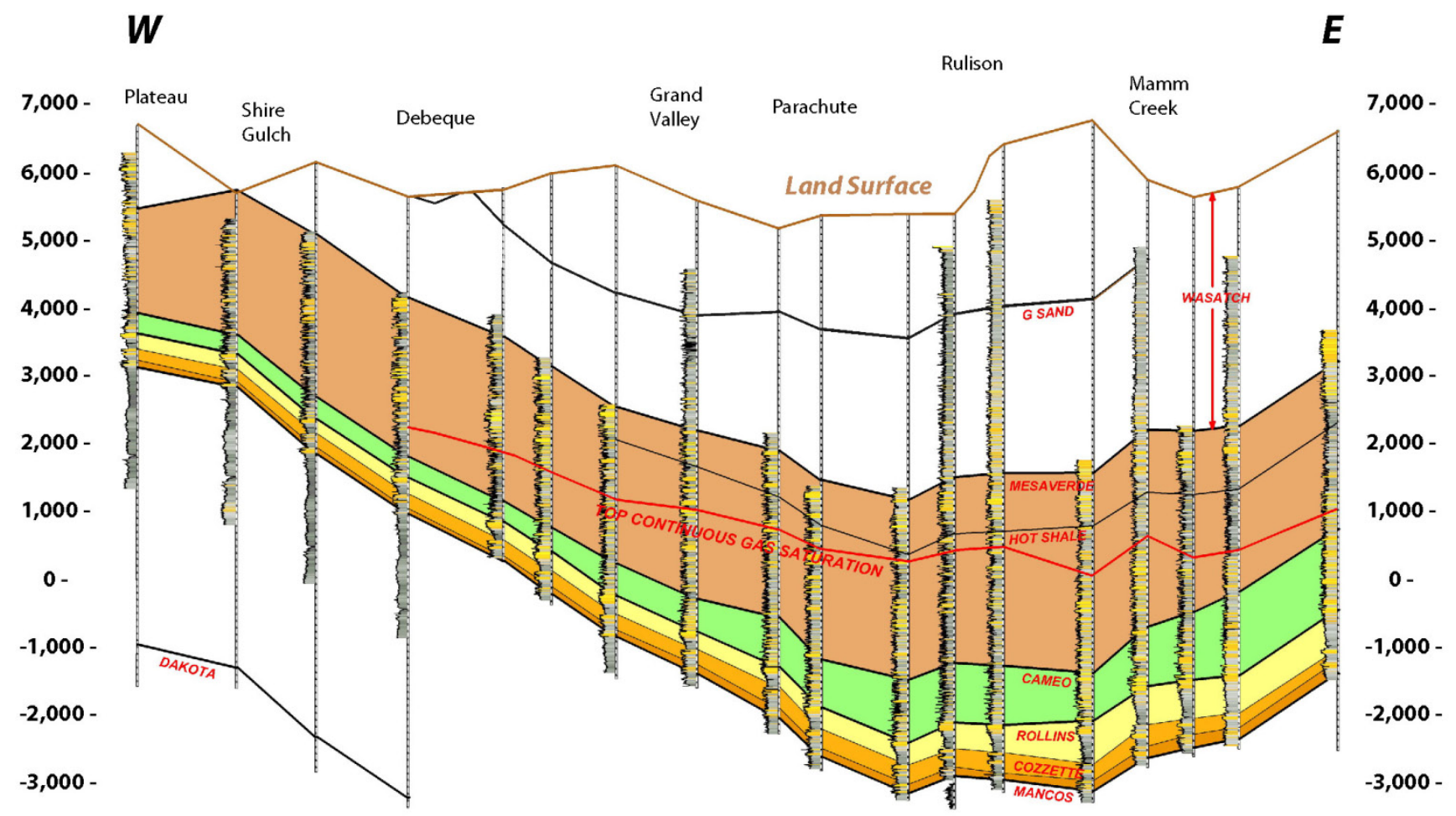

Figure 3. Cross section showing structural setting of Wasatch Formation and Mesaverde Group and gas fields, modified from Cumella and Ostby (2003). Location of cross section is labeled in figure 1 as "Fig. 3 structural section". Elevation is in feet relative to sea level. Gamma-ray logs are shaded to show sandstones in yellow and intervals with higher content of silt and clay in various shades of gray. Wasatch production examined in this report is from the $\mathrm{G}$ sand of the Wasatch Formation; Mesaverde production is from the interval between the base of the Cameo (Cameo coal zone) and the red line labelled "top continuous gas saturation."

\section{Data Reduction}

Daily production rates were computed by dividing monthly volumes of production by the number of days of production in a month. The resulting values of (1) gas rate, in thousands of cubic feet per day (mcf/day); (2) water rate, in barrels per day (bbl/day); and (3) oil rate, in barrels per day (bbl/day) are plotted on a logarithmic scale as a function of time (fig. 4A). Production versus time plots for selected wells are shown in plates 1-6. To determine a representative flow rate of gas, oil, or water from a well, a 3-month time interval was selected early in the history of a given production record for which fluid production was judged to be representative of flow. This time interval, referred to as the "first sample" in this report, was generally selected to be about two years after commencement of production; such delay serves to eliminate early transients and changes in equipment, and reduces the likelihood that fracturing fluids are included in the water tally. The records of fluid production in the Bennett 32-10 well are of better quality than most production records, making the selection of the sample points relatively easy for this well. For the example in figure $4 A$, the production rates were averaged over the months of February-April 1997, resulting in the values posted in the figure. 

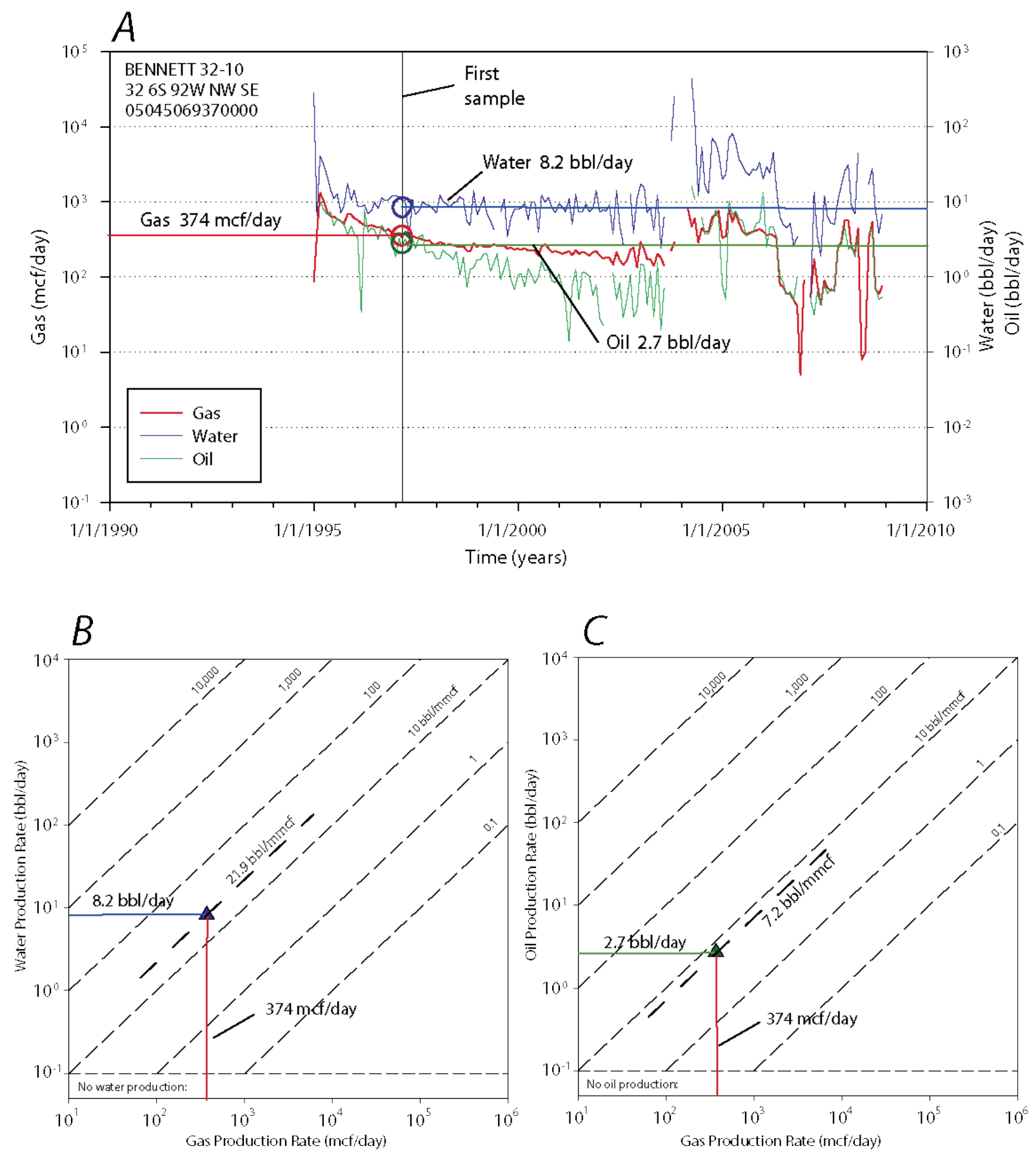

Figure 4. Example plot of fluid production versus time with corresponding bi-logarithmic production plots for the Bennett 32-10 well in Mamm Creek field. A, Production of gas, water, and oil versus time. Vertical line indicates the first sample, which is generally about two years after the onset of production. Posted values are averages for months of February-April 1997. B, Water versus gas production on logarithmic axes. Triangle symbol shows water and gas rate values from part A. The water-gas ratio of $21.9 \mathrm{bbl} / \mathrm{mmcf}$ falls on a $45-$ degree line. $C$, Oil versus gas production on logarithmic axes. Black triangle shows oil and gas rates from part A. The oil-gas ratio of $7.2 \mathrm{bbl} / \mathrm{mmcf}$, equivalent to a gas-oil ratio of $138,481 \mathrm{scf} / \mathrm{bbl}$, falls on a 45 -degree line. [mcf/day, thousand cubic feet per day; scf/bbl, standard cubic feet per barrel; bbl/mmcf, barrels per million cubic feet] 
The resulting average daily rates are posted on summary plots with bi-logarithmic scales (figs. $4 B$ and $4 C$ ), which accommodate wide ranges of production rates. With the use of bi-logarithmic axes, constant ratios of production rates lie on 45-degree lines, the ratio increasing upward and to the left. Other advantages of bi-logarithmic plots over linear plots are discussed by Nelson and others (2009b). Water production of $8.2 \mathrm{bbl} /$ day and gas production of $373.9 \mathrm{mcf} /$ day from well Bennett 32-10 determine the location of the single point in figure $4 B$. The water-gas ratio for this well, $21.9 \mathrm{bbl} / \mathrm{mmcf}$, which is represented as a diagonal line, is greater than the median for the wells examined in this study from the Mamm Creek field. In similar fashion, the first-sample oil rate of $2.7 \mathrm{bbl} /$ day and gas rate of $373.9 \mathrm{mcf} /$ day determine the location of the point in figure $4 C$, with a resulting oil-gas ratio of 7.2 $\mathrm{bbl} / \mathrm{mmcf}$ represented by a diagonal line. Wet gases, also called condensate gases, have gas-oil ratios in excess of 50,000 scf/bbl, or oil-gas ratios of less than $20 \mathrm{bbl}$ of condensate/mmcf of gas (McCain, 1990), and occupy the lower right corner of the plot. Thus, the representative data point in figure $4 C$ lies within the wet gas field.

To show the change in gas and water production in each well, a second 3-month average is computed 5 years after the first average (fig. $5 A$ ). The gas and water production figures from the second sample are plotted on the bi-logarithmic production plot (red circle in fig. $5 B$ ). Each second-sample value is linked to its first-sample value (triangle in fig. $5 B$ ) by a line, producing a vector that shows the amounts and the change of water and gas production over 5 years. On a bi-logarithmic graph, a vector of a given length and angle represents the same fractional changes in daily gas and water production regardless of where it is positioned on the graph. In the example shown in figures 4 and 5, gas production decreases from 374 to $210 \mathrm{mcf} /$ day over 5 years, water production increases from 8.2 to 10.0 $\mathrm{bbl} /$ day over 5 years, and the water-gas ratio increases from $21.9 \mathrm{bbl} / \mathrm{mmcf}$ (fig. $4 B$ ) to $47.4 \mathrm{bbl} / \mathrm{mmcf}$ (fig. $5 B$ ) over 5 years. 

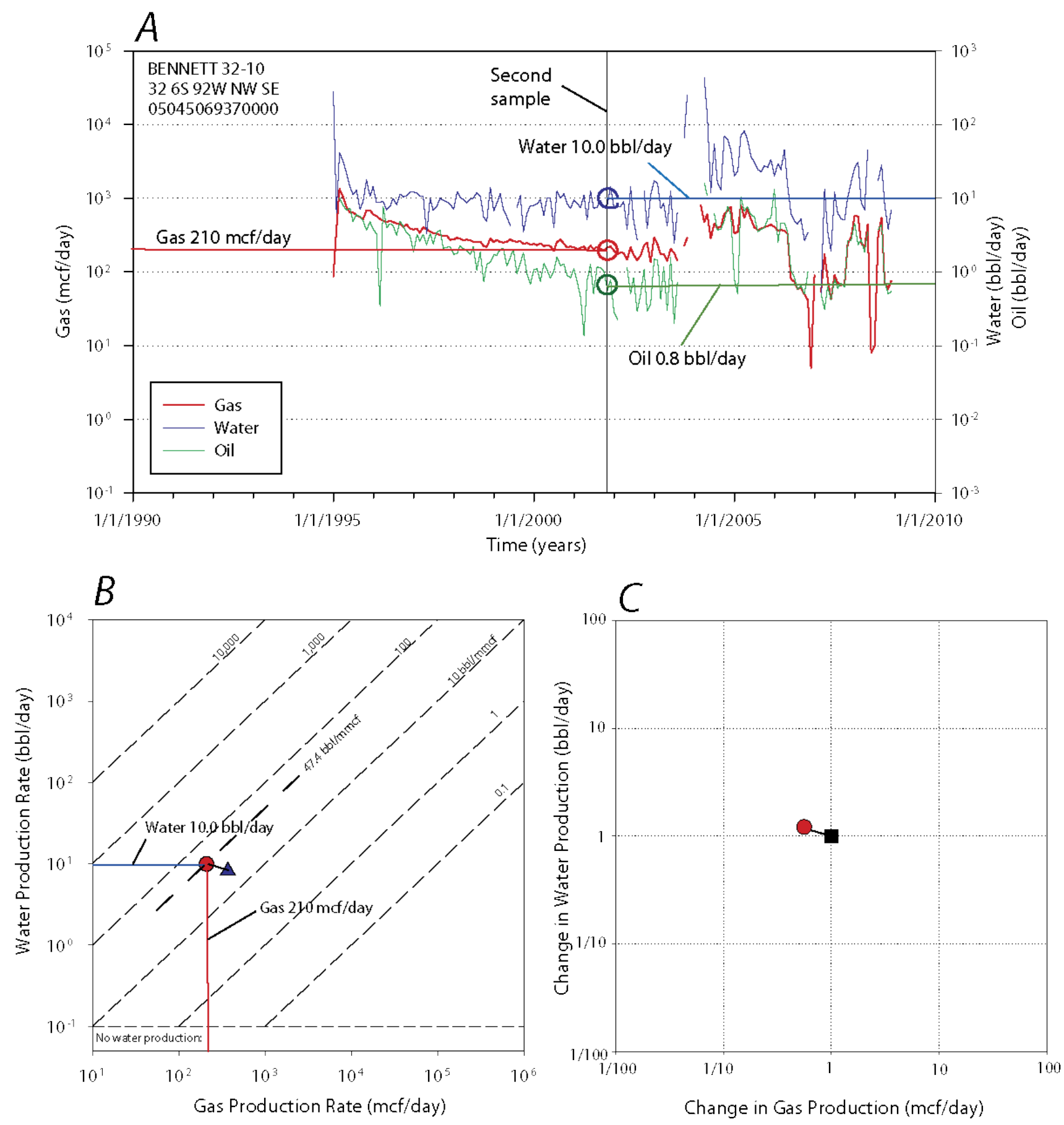

Figure 5. Example plot of fluid production versus time with vector plots of changes in production with time, for the Bennett 32-10 well in Mamm Creek field. A, Production of gas, water, and oil versus time with values given for the second sample. $B$, Vector plot, with water versus gas production on logarithmic axes. The triangle designates the gas and water production at the first sample and the red circle shows production at the second sample five taken five years later, thus marking the head and tail of a vector. C, Normalized vector plot, with change in water production versus change in gas production on logarithmic axes. Values from the first sample are placed at center of plot, so all vectors for a field share a common origin. [mcf/day, thousand cubic feet per day; bbl/mmcf, barrel per million cubic feet] 
To clarify the relative changes in water and gas production among wells, a bi-logarithmic plot of the change in water and gas production places all early-time production at a common origin (single square at 1,1 in fig. $5 C$ ), so that changes in production over a 5-year span can be compared among wells. The length and orientation of each vector is the same in figures $5 B$ and $5 C$, but the first-sample value has been normalized, or translated to the center $(1,1)$ position of the plot in figure $5 C$. In this example, gas, water, and oil records were complete so a second sample could be obtained 5 years after the first sample, but in a few cases where data were missing, values from an earlier time (three or four years after the first sample) were extrapolated to obtain a second sample.

As some water can exist as a dissolved phase in gas within the reservoir, the question arises as to how much of the produced water was originally dissolved in the reservoir and then condensed at the surface. The amount of water dissolved in gas in reservoirs increases with increasing temperature and decreases with increasing pressure (McCain, 1990, p. 460). The amount released depends upon the pressure and temperature at the surface; a fixed value of 33 pounds per $\mathrm{mmcf}(\mathrm{lb} / \mathrm{mmcf})$ was assumed, based on considerations by McCain (1990). Our computations, based upon the approach given by McCain (1990, p. 460-463) and using subsurface temperature and pressure conditions from various sources, indicate that the amount of water likely to be dissolved in reservoir gas and subsequently produced at the surface ranges from 0.21 to $0.47 \mathrm{bbl} / \mathrm{mmcf}$ among the four fields considered here (table 1). These estimates are included as diagonal lines on water-gas plots showing production from the Mesaverde Group on plates 3-6 to indicate how much of the water produced at surface could originate as water originally dissolved in reservoir gas. 
Table 1. Estimates of water released at the surface that was originally dissolved in gas in the reservoir. The estimates are based on pressure and temperature conditions corresponding to selected depths in four gas reservoirs producing from the Mesaverde Group. Solubility of water in gas and estimate of water retained of $33 \mathrm{lb} / \mathrm{mmcf}$ are taken from McCain (1990). Values in final column establish the blue diagonal lines in figures 32 of plate 3, 4-2 of plate 4, 5-2 of plate 5, and 6-2 of plate 6 . [ft, feet; psi, pounds per square inch; lb/mmscf, pounds per million standard cubic feet; cf/mmscf, cubic feet per million standard cubic feet; bbl/mmscf, barrel per million standard cubic feet]

\begin{tabular}{|c|c|c|c|c|c|c|c|c|c|c|}
\hline Field name & Depth in reservoir & Depth & Temperature & Pressure & $\begin{array}{r}\text { Solubility of } \\
\text { water in gas }\end{array}$ & $\begin{array}{c}\text { Correction } \\
\text { factor }\end{array}$ & $\begin{array}{l}\text { Water } \\
\text { retained }\end{array}$ & \multicolumn{3}{|c|}{ Water released at separator } \\
\hline & & $(\mathrm{ft})$ & $\left({ }^{\circ} \mathrm{F}\right)$ & (psi) & (lb/mmscf) & (Ib/mmscf) & (lb/mmscf) & (Ib/mmscf) & (cf/mmscf) & (bbl/mmscf) \\
\hline Grand Valley & Median top depth & 4,797 & 148 & 2,077 & 110 & 108 & 33 & 75 & 1.20 & 0.21 \\
\hline Grand Valley & Median bottom depth & 6,292 & 182 & 4,090 & 182 & 178 & 33 & 145 & 2.33 & 0.42 \\
\hline Parachute & Median top depth & 5,295 & 159 & 2,293 & 160 & 157 & 33 & 124 & 1.98 & 0.35 \\
\hline Parachute & Median bottom depth & 6,576 & 188 & 4,603 & 180 & 176 & 33 & 143 & 2.30 & 0.41 \\
\hline Rulison & Median top depth & 5,420 & 162 & 2,347 & 170 & 167 & 33 & 134 & 2.14 & 0.38 \\
\hline Rulison & Median bottom depth & 7,179 & 202 & 5,800 & 200 & 196 & 33 & 163 & 2.61 & 0.47 \\
\hline Mamm Creek & Median top depth & 4,724 & 146 & 2,045 & 115 & 113 & 33 & 80 & 1.28 & 0.23 \\
\hline Mamm Creek & Median bottom depth & 5,925 & 173 & 3,259 & 160 & 157 & 33 & 124 & 1.98 & 0.35 \\
\hline
\end{tabular}


Because oil and gas types are defined as a function of gas-to-oil ratios (McCain, 1990), the fluid types can be displayed on the log-log oil production versus gas production diagrams (fig. 6). Black oil types have gas-oil ratios less than 2,000 standard cubic feet per barrel (scf/bbl) and volatile oil types have gas-oil ratios of less than $3,300 \mathrm{scf} / \mathrm{bbl}$ of oil, and together they occupy the upper left corner of an oil-gas production diagram (fig. 6). In a retrograde gas reservoir, liquid condenses in the reservoir as reservoir pressure declines. Gas-oil ratios in retrograde gas reservoirs typically range from 3,300 to $50,000 \mathrm{scf} / \mathrm{bbl}$, although they can have values as high as 150,000 scf/bbl; these reservoirs occupy a central diagonal band on an oil-gas diagram (fig. 6). Wet gases, also called condensate gases, have gasoil ratios in excess of 50,000 scf/bbl (less than $20 \mathrm{bbl}$ condensate/mmcf gas) and occupy the lower right corner of the diagram. Dry gas produces no oil in either the reservoir or at the surface (McCain, 1990), and corresponding points are plotted in a separate rectangular box at the bottom of the diagram.

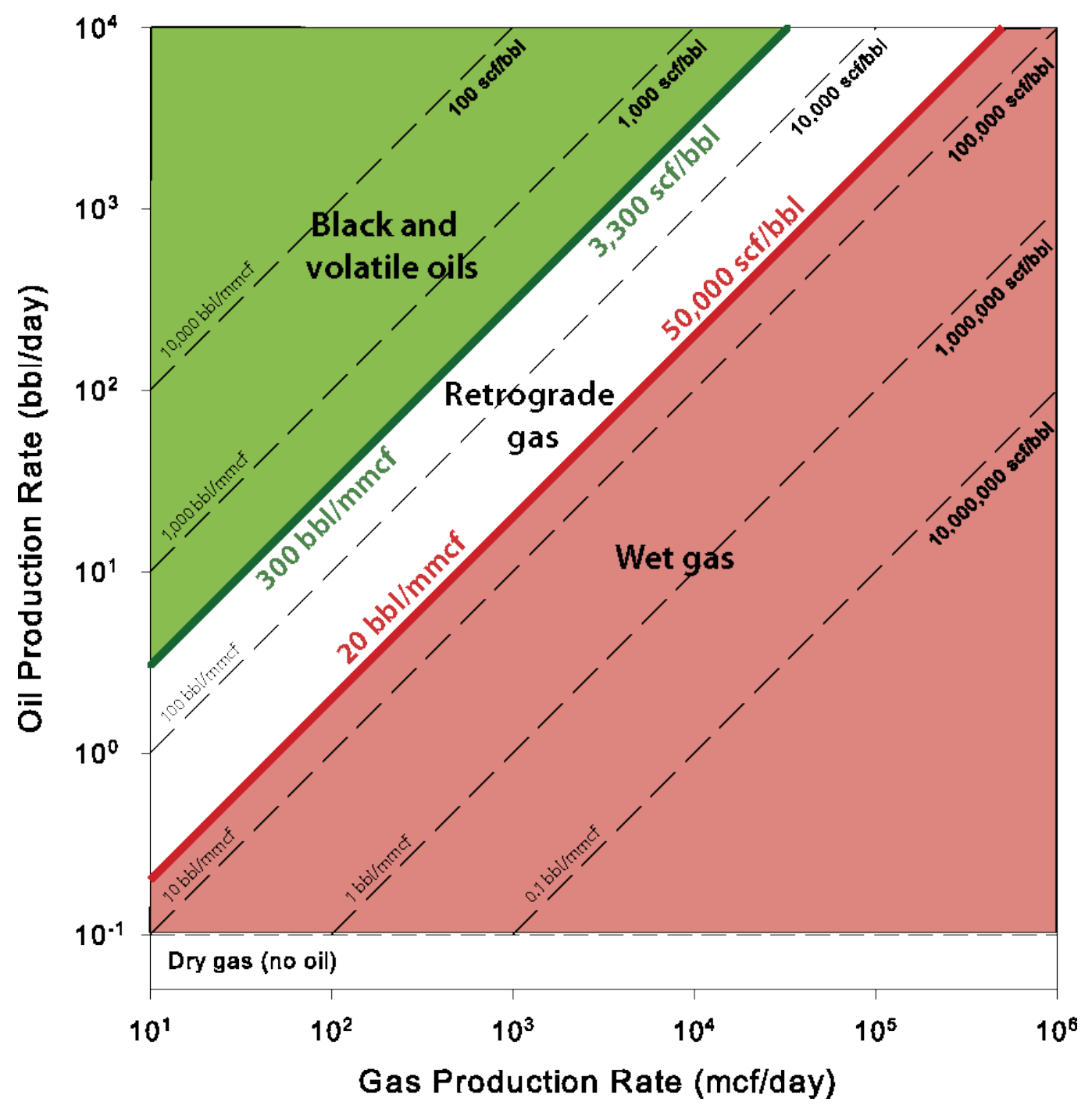

Figure 6. Oil and gas types plotted on a log-log diagram of oil and gas production rates. Fields indicate three reservoir fluid types, based on McCain (1990). [scf/bbl, standard cubic feet per barrel; bbl/mmcf, barrels per million cubic feet; bbl/day, barrels per day; mcf/day, thousand cubic feet per day] 
Maps, production plots for selected wells, and summary plots of data are presented in plates 1-6 for Grand Valley, Parachute, Rulison, and Mamm Creek fields. No oil or water was produced from the Wasatch Formation, so only gas is reported on plates 1 and 2. Oil and water production from the Mesaverde Group was consistent enough to be displayed and summarized from Grand Valley, Rulison, and Mamm Creek fields (plates 3, 5, 6), but reporting of oil and water production from the Parachute field was sporadic, so only gas is reported from the Mesaverde Group from that field (plate 4). The six appendixes contain the location of each well and numerical values of fluid production from the first and second samples. Production records and other data for this study were drawn from the IHS Energy production database (IHS Energy, 2009). Well locations were taken from the Web site of the Colorado Oil and Gas Conservation Commission (accessed April 2010 at http://cogcc.state.co.us/).

\section{Production from the Wasatch $\mathrm{G}$ Interval}

Production data were obtained from the IHS database (IHS Energy, 2009), selected by field name with the date of first production restricted to earlier than December 31, 1998. Gas is produced from the Wasatch Formation in Parachute and Rulison fields but not in the Grand Valley or Mamm Creek fields. Of the 26 wells selected in the Parachute field, production in 22 wells commenced in the years 1986-1990, with production from 4 other wells commencing in 1991, 1992, 1994, and 1996. Of the 38 wells selected in Rulison field, production commenced in years 1984-1985 (17 wells), in 19891991 (19 wells), and in 1995-1996 (2 wells).

In Parachute field, the surface locations of four northern wells-Allen Point 1-1695, 1-2095, 18-95, and Mobil 1-9-95 — are at elevations several thousand feet higher than the other 22 wells, for which the depths of the perforation mid-points range from 1,100 to 2,709 $\mathrm{ft}$ with an average of 1,740 ft (appendix 1). In Rulison field, depths of perforation mid-points for 38 wells range from 1,400 to 2,450 $\mathrm{ft}$ with an average depth of 1,842 ft (appendix 2).

The Wasatch Formation is completed and produced separately from the underlying Mesaverde Group. Most wells were completed (hydraulically fractured) within a single interval, although a few wells required two or three completion intervals (appendixes 1 and 2). Based on the thickness of the perforated intervals in Parachute field (appendix 1), the gas examined in this study is produced only from the Wasatch $\mathrm{G}$ interval in 17 of the 26 wells. In the other wells, production is from the Wasatch $\mathrm{G}$ interval and a few deeper intervals within the Wasatch Formation.

In Parachute field, first-sample gas production from the 26 wells in the Wasatch G interval ranged from 40 to $642 \mathrm{mcf} /$ day, with individual well production distributed evenly within that range (fig. 1-2 of plate 1). Median and average values of first-sample gas production were 234 and 261 $\mathrm{mcf} /$ day (appendix 1). The average gas production rate declined to $108 \mathrm{mcf} /$ day after 5 years. Initial gas production was greatest, exceeding $400 \mathrm{mcf} /$ day, in wells located in sections 33, 34, and 35 of T. 6 S., R. 95 W. and in section 3 of T. 7 S., R. 95 W. The lowest production rates, less than 50 mcf/day, were in the three southeastern wells in sections 1, 2, and 11 of T. 7 S., R. 95 W.

In Rulison field, first-sample gas production from 38 wells ranged from 28 to 284 mcf per day; in this field, gas production appears to be normally distributed (see distribution in fig. 2-2 of plate 2) around an average of $96 \mathrm{mcf} /$ day (appendix 2). Average gas production after five years (second sample) was $59 \mathrm{mcf} /$ day, with a range from 18 to $146 \mathrm{mcf} /$ day. First-sample gas production is not a strong function of well location, although wells with the lowest gas production rates are located on the east and west sides of the field.

Declines in gas production over the five years between the first and second samples are somewhat greater in Parachute field than in Rulison field as shown by the gas production plots (figs. 14 through 1-13 of plate 1 and figs. 2-4 through 2-13 of plate 2), the lengths of the change vectors (fig. 13 
of plate 1 and fig. 2-3 of plate 2), and the ratios of second sample/first sample average rates cited in the preceding paragraphs $(108 / 261=0.41$ for Parachute field and 59/96 $=0.61$ for Rulison field $)$.

Produced gas at the first sample and the decline of gas rate from the first to second sample were plotted (not shown) against (1) the number of perforations and (2) the depth extent of the perforated intervals, which are tabulated for each well in appendixes 1 and 2. No relationships were found between gas rate or gas-rate decline and either of these two completion parameters in either Parachute or Rulison fields.

No oil and very little water was produced from these wells. Water was produced from only 2 of the 26 wells in Parachute field, both on the periphery of the field, and may have been produced from an interval deeper than the Wasatch Formation in one of those two wells, well W-37-1. Only a few months of water production was reported for about half of the 38 wells in Rulison field. Using a temperature gradient of $1.8^{\circ} \mathrm{F}$ per $100 \mathrm{ft}$ (Warpinski and Lorenz, 2008), reservoir temperature at 1,800 $\mathrm{ft}$ is estimated to be $72^{\circ} \mathrm{F}$. Using a pressure-depth ratio of $0.3 \mathrm{psi} / \mathrm{ft}$, reservoir pressure is estimated to be $540 \mathrm{psi}$. At these low temperatures and pressures, gas can absorb only 0.1 bbl water per mmcf of gas (McCain, 1990), none of which may be released at the surface. Hence no dissolved water is expected to be produced. It is possible that small amounts of free water are dissolved in gas as it moves to lower pressures at the wellbore, in which case small amounts of free water produced from the formation could remain dissolved in gas at the surface and not be recorded.

\section{Production from the Mesaverde Group}

Production records for the Mesaverde Group were obtained from the IHS database (IHS Energy, 2009) for each of four fields - Grand Valley, Parachute, Rulison, and Mamm Creek — with the date of first production restricted to earlier than December 31, 1998. The selected wells are shown on maps on plates 3-6 and are listed in appendixes 3-6. Well selection was guided by the need for (1) examining fluid production as early in the life of the field as practical, (2) good continuity of records for gas, oil, and water, (3) good coverage of each field without spatial oversampling, and (4) a desired sample size of around 30 wells per field. Production commenced in the years 1983-1988 for most of the selected wells, with production commencing as early as 1990 or as late as 1998 for a few wells.

Many of the well completions done around 1990 in the Grand Valley and Parachute fields were dual completions, in which a packer was set above the Cameo coal interval (Reinecke and others, 1991). Gas was produced from a single Cameo interval through tubing extended through the packer. Gas was also produced from a single Mesaverde interval above the packer through the annulus between tubing and casing. Gas from the two intervals was metered separately in order to obtain favorable tax considerations for gas production attributed to coal beds in the Cameo interval. It was difficult to monitor the water produced from the tubing-casing annulus (called the "back side"), because the large annular area resulted in a reduced flow velocity that could not carry produced water to surface, with consequent water loading in the annulus (F. Farnham, retired geologist, oral commun., 2009). As a result, water records for the Mesaverde interval were incomplete. We elected not to use any records from wells with dual completions during the 1990-1997 time interval.

In 1997-1998, many wells in the Grand Valley and Parachute fields were re-entered and 2 or 3 completion intervals were added in shallower Mesaverde intervals. Wells that were re-entered are designated with a 01 or 02 as the last two digits in the American Petroleum Institute (API) number instead of 00 (appendixes 3-6). These re-completed wells were then put on production, generally incorporating the original two lower completion intervals. The number of completion intervals for each well is listed in appendixes 3-6. The first and second samples used in the present study were taken both from the re-completed wells and from wells first drilled in the 1995-1998 time period. In the case of 
the re-completed wells, our criterion of selecting the earliest production from a field was not met in Grand Valley and Parachute fields. The depth intervals, the number of perforations, and the number of completion intervals that were accessed during first and second sample times were determined by inspection of well records (IHS Energy, 2009) and forms submitted to the Colorado Oil and Gas Conservation Commission (accessed April 2010 at http://cogcc.state.co.us/).

Production startup from our selected wells in the four fields occurred mainly within the years 1993 through 1998, as indicated by the production records in plates 3-6. Cumella and Ostby (2003, p. 186) described the completion techniques used in this time period in Grand Valley, Parachute, and Rulison fields: "A typical Williams Fork well is completed in 4 to 6 gross intervals that average 300$400 \mathrm{ft}$ thick. The average number of sands that are present in each interval is 3 to 5 . Hydraulic fracture treatments use limited-entry techniques with 100,000 to 400,000 lbs of sand in each treatment. Most hydraulic fracture treatments in the last three years have been slickwater fracs that use 1,000 to 3,000 barrels of fluid per frac treatment."

\section{Grand Valley Field}

In Grand Valley field, first-sample gas production ranges from 132 to $695 \mathrm{mcf} /$ day, with median and average values of 282 and $296 \mathrm{mcf} /$ day, respectively (fig. 3-2 of plate 3 and appendix 3). After five years (second sample), gas production declined to median and average values of 128 and $155 \mathrm{mcf} / \mathrm{day}$, that is, to about half that of the first sample. Eleven of 27 wells produced oil (condensate) at rates less than $1.2 \mathrm{bbl} /$ day at the first sample, but no oil was recorded for the other 16 wells (fig. 3-3 of plate 3). All 27 wells produced water at both the first and second samples; the eight production records (figs. 3-6 through 3-15 of plate 3 ) show that water production was nearly continuous with time in individual wells. First-sample water production ranged from 0.6 to $6.7 \mathrm{bbl} /$ day and second-sample water ranged from 0.3 to $9.0 \mathrm{bbl} /$ day; water production increased from first to second samples in one-half of the wells and decreased in the other half (fig. 3-5 of plate 3). However, the average water production rate was unchanged at $2.67 \mathrm{bbl} /$ day in both the first and second samples. With average gas production declining by half and average water production remaining unchanged, the average water-gas ratio increases by about a factor of two over the five-year period between the first and second samples.

It might be expected that oil or water production rates would be greater in some parts of the field than in other locations. However, we observed no spatial dependence or grouping for either oil or water production.

\section{Parachute Field}

Production records for the Parachute field are continuous for gas but show only sporadic production of oil and water. The incomplete nature of the oil and water records contrasts with the nearly continuous records from the Grand Valley, Rulison, and Mamm Creek fields, as can be seen by comparing plate 4 with plates 3,5 , and 6 . It is not known why the reported fluid production is different for Parachute field. As a consequence, water data are available for the first sample in 16 of 20 wells (fig. 4-2 of plate 4) and for the second sample in 12 of 20 wells (appendix 4). Due to the lack of continuity in the water records, change vectors were not plotted. The changes in gas production are discussed in a later section of this report.

\section{Rulison Field}

Gas, oil, and water records selected from Rulison field show good continuity (figs. 5-6 through 5-15 of plate 5). Gas production at the first sample ranges from 125 to $861 \mathrm{mcf} /$ day, with two additional 
high-rate wells yielding 1,695 and 1,992 mcf/day (fig. 5-3 of plate 5). Median and average first-sample gas production rates are 340 and $485 \mathrm{mcf} /$ day, respectively (appendix 5). Median and average water production first-sample rates are 2.2 and $3.5 \mathrm{bbl} /$ day. The oil-gas ratios of individual wells are between 1 and $10 \mathrm{bbl} / \mathrm{mmcf}$, and the average oil-gas ratio is $3.65 \mathrm{bbl} / \mathrm{mmcf}$, all within the wet gas field of fig. 6 . Water-gas ratios are tightly distributed (fig. 5-2 of plate 5) with an average ratio of $7.5 \mathrm{bbl} / \mathrm{mmcf}$ at the first sample. However, the changes in water and gas between the first and second samples vary widely (fig. 5-5 of plate 5). For example, water decreases by more than a factor of 5 in 9 wells and increases in 5 other wells, whereas the ratio of gas at the second sample to gas at the first sample ranges from 0.07 to 1.43 .

\section{Mamm Creek Field}

Like the Rulison field, Mamm Creek production records exhibit good continuity, making sample selection fairly straightforward (figs. 6-6 through 6-15, plate 6). Gas production at the first sample ranges from 53 to $1,040 \mathrm{mcf} / \mathrm{day}$, with a median value of $249 \mathrm{mcf} /$ day. Mamm Creek field is characterized by high water production rates in a few of the sampled wells. Three wells on the southwest edge of the field-Parker 10-9, Parker 14-10, and Bennett 32-10 - have first-sample water production rates of 8 to $14 \mathrm{bbl} /$ day. Two wells on the southern edge of the field-Mamm Creek 29-4 and HMV 30-16 - have rates of 9.7 and $5.4 \mathrm{bbl} / \mathrm{day}$. The highest rate water producer - Covey 5-10 - is in the center of the field (fig. 6-1 of plate 6). Despite these few wells with high rates, water production from the typical (median) well in Mamm Creek field is about the same as in the other three fields. The median water/gas ratio is $6.4 \mathrm{bbl} / \mathrm{mmcf}$.

\section{Discussion}

\section{Gas Production from the Wasatch G Interval}

The amounts of gas produced at the first and second samples, and the changes between the first and second samples, can be examined in figure 7 for both the Wasatch $\mathrm{G}$ interval and the Mesaverde Group. Gas production from the Wasatch G interval was substantially greater from the Parachute field than from the Rulison field, and the median gas production from Parachute-Wasatch is similar to median gas production from the four fields producing from the Mesaverde Group (fig. 7). As discussed previously, the outstanding characteristic of Wasatch $\mathrm{G}$ production is the lack of oil and water production.

\section{Underpressuring in the Wasatch G Interval}

The presence of the underpressured gas-producing Wasatch $\mathrm{G}$ interval overlying the overpressured gas-producing Mesaverde Group poses an interesting question - how did the underpressure (less than hydrostatic) of the Wasatch $\mathrm{G}$ interval evolve? Besides being underpressured (pressure-depth ratios of 0.35 and 0.36 were cited previously for the Parachute and Rulison fields), gas has been produced from the Wasatch $\mathrm{G}$ interval for long periods without water production (plates 1,2). The hypothesis advanced here is that the underpressured condition and the lack of water production both evolved late in the geologic history of the basin as a consequence of uplift and erosion: as much as $5,000 \mathrm{ft}$ of overburden were removed from the Wasatch $\mathrm{G}$ interval from maximum burial to present day (fig. 8). In Parachute field, the present-day depth to the mid-point of the Wasatch G interval is at a relatively shallow depth of approximately $1,740 \mathrm{ft}$. Because gas volume is inversely proportional to pressure, gas volumes increase with uplift and erosion, and increase greatly for reservoirs that come to a 
shallow burial depth at the present day (Brown, 2005). The expansion of gas is believed to be the cause of the near absence of produced water and the apparent absence of a gas-water contact. Erosional processes have exposed the Wasatch G interval at the surface to the east and southwest of Parachute and Rulison fields, with the lowest elevation outcrops located where the interval is bisected by the Colorado River (figs. 1 and 3). The hydraulic connection between surface and reservoir is believed to be the cause of the apparent underpressure.

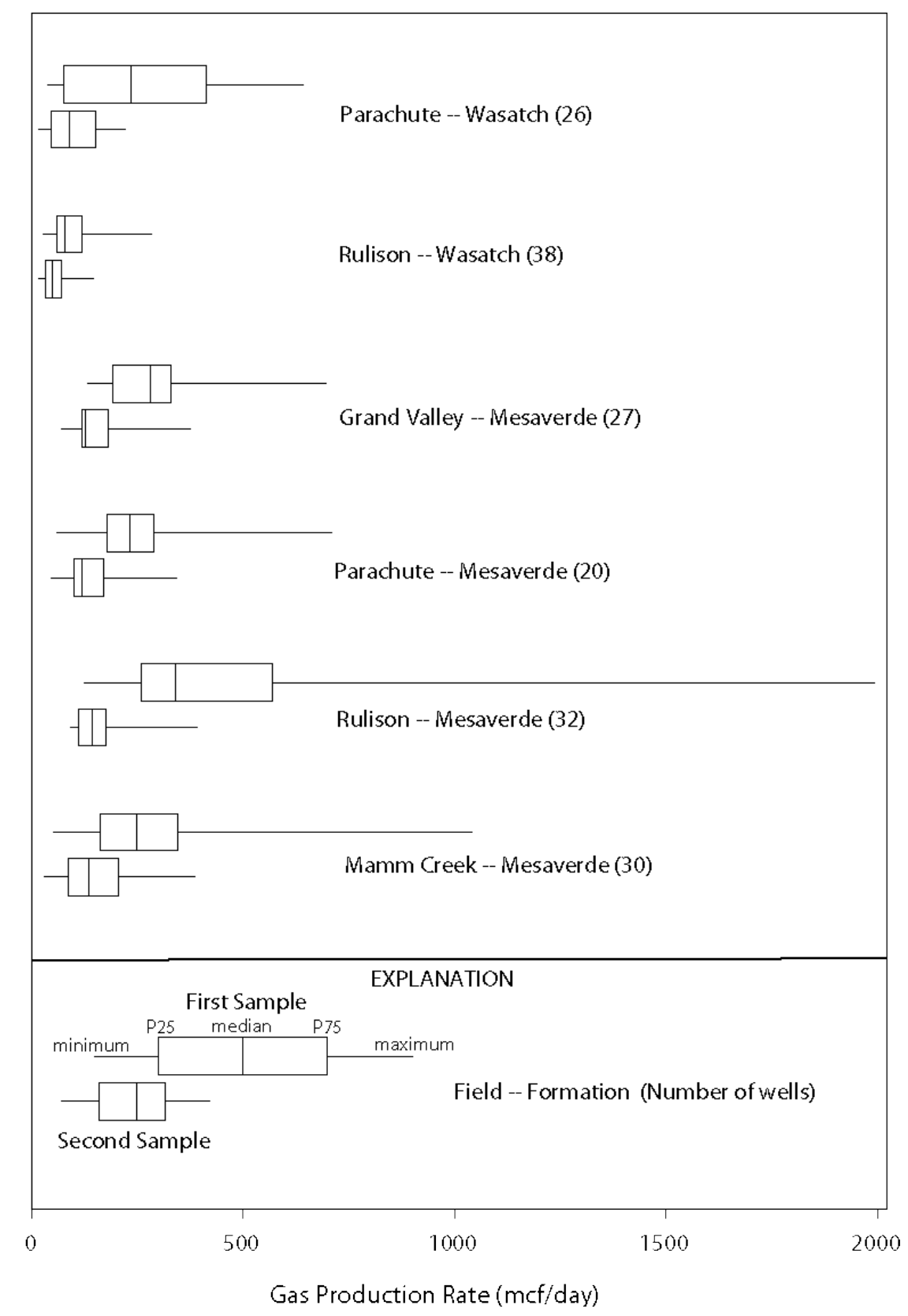

Figure 7. Box and whiskers plot of gas production at the first and second samples for the Wasatch Formation and the Mesaverde Group. Each whisker and each box represents one-fourth of the population; the left edge of the box represents the 25th percentile and the right edge, the 75th. The shift from the upper box-and-whiskers to the lower one shows the decline in gas production rates over a five-year time period. 
Outcrops of the Wasatch G interval are present both east (upstream) and southwest (downstream) of the Parachute and Rulison gas fields (fig. 1). Consequently, the Wasatch G interval is charged with surface water, especially where outcrops are bisected by the Colorado River in T. 8 S., R. 97 W., and in T. 6 S., R. 92-91 W. In the following computational exercise, we assume that the gas pressure in Parachute field is controlled by hydraulic linkage to the outcrop in T. 8 S., R. 97 W. (which is at an elevation of approximately 5,200 ft) and not to the outcrop at T. 6 S., R. 92-91 W (which is at a higher elevation of approximately 5,800 ft) (fig. 8). Analysis of fracture patterns from aeromagnetic and seismic surveys shows a denser network of fracturing at shallow depths to the east of the Parachute field than to the west, indicating a higher likelihood that the hydraulic continuity of the $G$ interval has been disrupted by faulting between Parachute field and the eastern outcrops (Hoak and Klawetter, 1997).

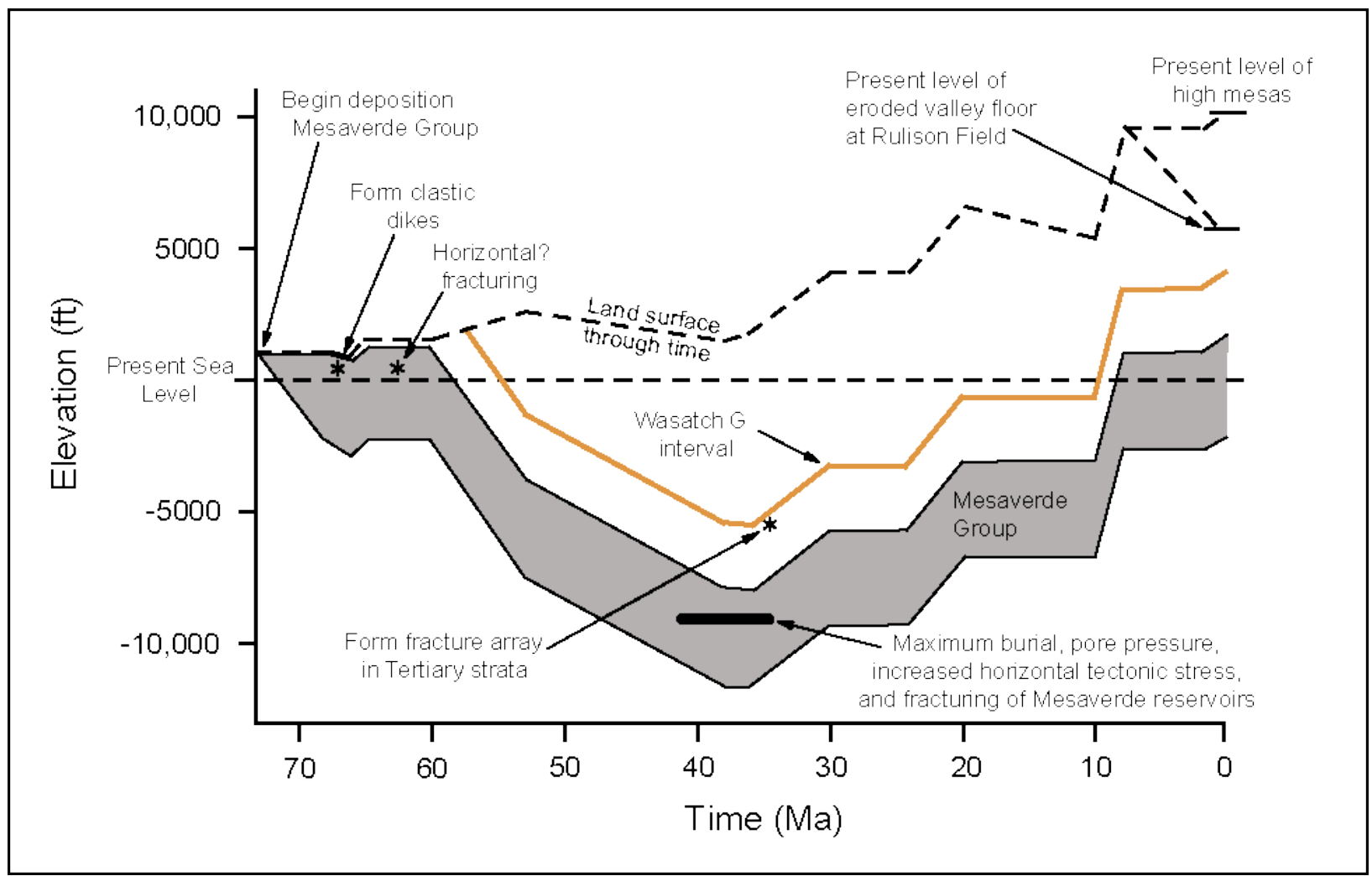

Figure 8. Elevation of land surface and key geologic horizons in Rulison field as a function of time, after Lorenz and Finley (1991, American Association of Petroleum Geologists Bulletin, AAPG@1991, reprinted by permission of the AAPG whose permission is required for further use).

To compute the elevation of the water-gas interface (location 4 in fig. 9), we consider the pressure $P_{2}$ in the gas reservoir at location 2 and the pressure $P_{4}$ in the water at location 4:

and the water pressure at location 4 must be

$$
P_{2}=0.350 \times\left(Z_{1}-Z_{2}\right)
$$

The two pressures are related by

$$
P_{4}=0.433 \times\left(Z_{3}-Z_{4}\right)
$$

where

$$
P_{4}=P_{2}-0.017 \times\left(Z_{4}-Z_{2}\right)-P_{c}
$$


$0.350 \mathrm{psi} / \mathrm{ft}$ is the pressure-depth ratio in Parachute field,

$0.433 \mathrm{psi} / \mathrm{ft}$ is the pressure gradient of fresh water,

$0.017 \mathrm{psi} / \mathrm{ft}$ is the pressure gradient of gas in the Wasatch $\mathrm{G}$ interval at location 2 , $Z_{i}, \mathrm{i}=1,2,3,4$ is the elevation at locations $1-4$ in figure 9 ,

and

$P_{c}$ is the pressure drop across the interface between water and gas.

The second term in equation 3 is small relative to other terms in equations 1 and 2 because 0.017, which represents the gas density, is smaller than the other two pressure-depth ratios and the elevation difference between points 2 and 4 is considerably smaller than $Z_{1}-Z_{2}$ or $Z_{3}-Z_{4}$. Solving for $Z_{4}$, $Z_{4}=\left[Z_{3}-(0.350 / 0.433) \times\left(Z_{1}-Z_{2}\right)-(0.017 / 0.433) \times Z_{2}+P_{c} / 0.433\right] /(1-(0.017 / 0.433))$

Three elevation values are needed to evaluate equation 4 . Seventeen wells from Parachute field were used to compute representative elevations of $Z_{1}$ and $Z_{2}$. Their average surface elevation was used to establish $Z_{I}=5,521 \mathrm{ft}$. The elevation of the mid-point of the Wasatch $\mathrm{G}$ interval ranged from $3,161 \mathrm{ft}$ to $4,060 \mathrm{ft}$, with an average of 3,686 ft. Because an elevation near the top of the gas accumulation could be determining the location of the water-gas interface, a second value based on the average plus one standard deviation was also chosen, yielding two test values of $Z_{2}=3,686 \mathrm{ft}$ and $Z_{2}=3,940 \mathrm{ft}$. The outcrop elevation, $Z_{3}=5,200 \mathrm{ft}$, is based on the surface elevation where the Colorado River intersects outcrops of the Wasatch G interval in T. 8 S., R. 97 W.

An estimate of the pressure drop $P_{c}$ raises a difficult question, as the nature of an updip-water, downdip-gas interface is not understood, as opposed to updip-gas, downdip-water scenarios that are well understood in the context of buoyant systems with top seals. However, there is no evidence that the gas reservoir in the Wasatch $\mathrm{G}$ interval behaves as a buoyant system; in fact, the production of gas without water indicates that it is not a buoyant system. One solution to the problem rests on the concept of gas bubbles trapped in pore spaces between changes in grain (pore throat) sizes (Shosa and Cathles, 2001). Shosa and Cathles explain the results of their experiment on the basis of a capillary block that incorporates gas bubbles at grain-size interfaces that block the flow of water from coarse- to finegrained strata.

The model is appealing for the case at hand, as uplift of the gas reservoir caused gas expansion, forcing the gas-water interface to expand outward from the initial gas bubble. Exsolution of gas from water upon further pressure reduction produced free gas that blocked and continues to block any reverse flow of water into pore space formerly occupied by water but presently occupied by gas. The magnitude of the pressure drop across one layer of fine-grained strata is about 34 psi (Shosa and Cathles, 2001). Successive layers of coarse- to fine-grained strata would provide additive pressure confinement, so the total pressure drop could be $n \times 34$ where $n$ is the number of layers. In our case, the number of layers is unknown; we will assume 1 to 3 such intervals, providing a range of possible pressure drops of 34 to 102 psi. Application of equation 4 yields the data shown on table 2 . 
Table 2. Elevation of the water-gas transition zone in the Wasatch $\mathrm{G}$ interval, for two assumed values of elevation of the gas reservoir and three assumed values of capillary pressure drop across the water-gas transition zone. Points 2 and 4 refer to locations in figure 9 . [ft, feet; psi, pounds per square inch]

\begin{tabular}{cccccc}
\hline $\begin{array}{c}\text { Elevation } \\
\text { of gas } \\
\text { reservoir } \\
\text { at point } 2\end{array}$ & $\begin{array}{c}\text { Number } \\
\text { of } \\
\text { capillary } \\
\text { barriers }\end{array}$ & $\begin{array}{c}\text { Capillary } \\
\text { pressure } \\
\text { drop } P_{c}\end{array}$ & $\begin{array}{c}\text { Elevation } \\
\text { of } \\
\text { water-gas } \\
\text { transition }\end{array}$ & $\begin{array}{c}\text { Water } \\
\text { pressure } \\
\text { at point } 4\end{array}$ & $\begin{array}{c}\text { Gas } \\
\text { pressure } \\
\text { at point } 4\end{array}$ \\
\hline 3,686 & 1 & 34 & 3,799 & 606 & 640 \\
& 2 & 68 & 3,881 & 571 & 639 \\
3,940 & 3 & 102 & 3,963 & 536 & 638 \\
& 1 & 34 & 4,003 & 518 & 637 \\
& 2 & 68 & 4,084 & 483 & 636 \\
& 3 & 102 & 4,166 & 448 & 634 \\
\hline
\end{tabular}

The second case, for $Z_{2}=3,940 \mathrm{ft}$, is illustrated in figure 9. The lateral location of the water-gas transition is poorly constrained in our two-dimensional representation (fig. 9) of a poorly mapped threedimensional surface, and the elevation of the transition is uncertain because of our lack of knowledge regarding $P_{c}$ and the effective elevation of the gas-charged interval. Thus, the computations in table 2 are presented in the form of a sensitivity analysis showing the possible range of elevation of the watergas transition zone, rather than an exact result. The important point is that the surface elevation at Parachute field that was used to compute an apparent pressure gradient of $0.35 \mathrm{psi} / \mathrm{ft}$ is higher than the outcrop elevation, which controls the pressure at the water-gas interface. The elevation of the water-gas transition zone is not far above the elevation of the gas reservoir, about $100 \mathrm{ft}$ according to table 2 . This seems to be a reasonable estimate, as the equilibration point for gas expansion is not far above the maximum gas elevation in the reservoir. Water and gas pressures at the transition zone are also given in table 2; the differences between the two are equal to the assumed value of the capillary pressure drop.

\section{Gas Production from the Mesaverde Group}

Of the four fields producing from the Mesaverde Group, the Rulison field has the highest average production rate and the greatest number of highly productive wells. The highest gas production of $1,992 \mathrm{mcf} /$ day is nearly twice that of the highest producer in the other three fields, and the skewness to highly productive wells is shown by the elongated box and whisker above the median (fig.7). The distributions of other fields are more symmetric than that of Rulison-Mesaverde (fig.7).

Ratios of gas production at the second sample to the first sample are provided in appendixes 3-6 and are also shown as histograms in table 3 . The distributions are roughly normal, with about the same number of samples above and below the mode. Rulison field, with its mode in the $0.30-0.39$ range, again stands apart from the other three fields, which have modal and median values in the $0.50-0.59$ range. Other statistics, taken from appendixes 3-6, are given in table 3. Overall, gas production decreased by about one-half over the five-year span between the second and seventh years of production. It is noteworthy that Rulison field had the greatest decline $(0.40)$ over a five-year time span and also had the greatest number of wells with high first-sample gas production. 


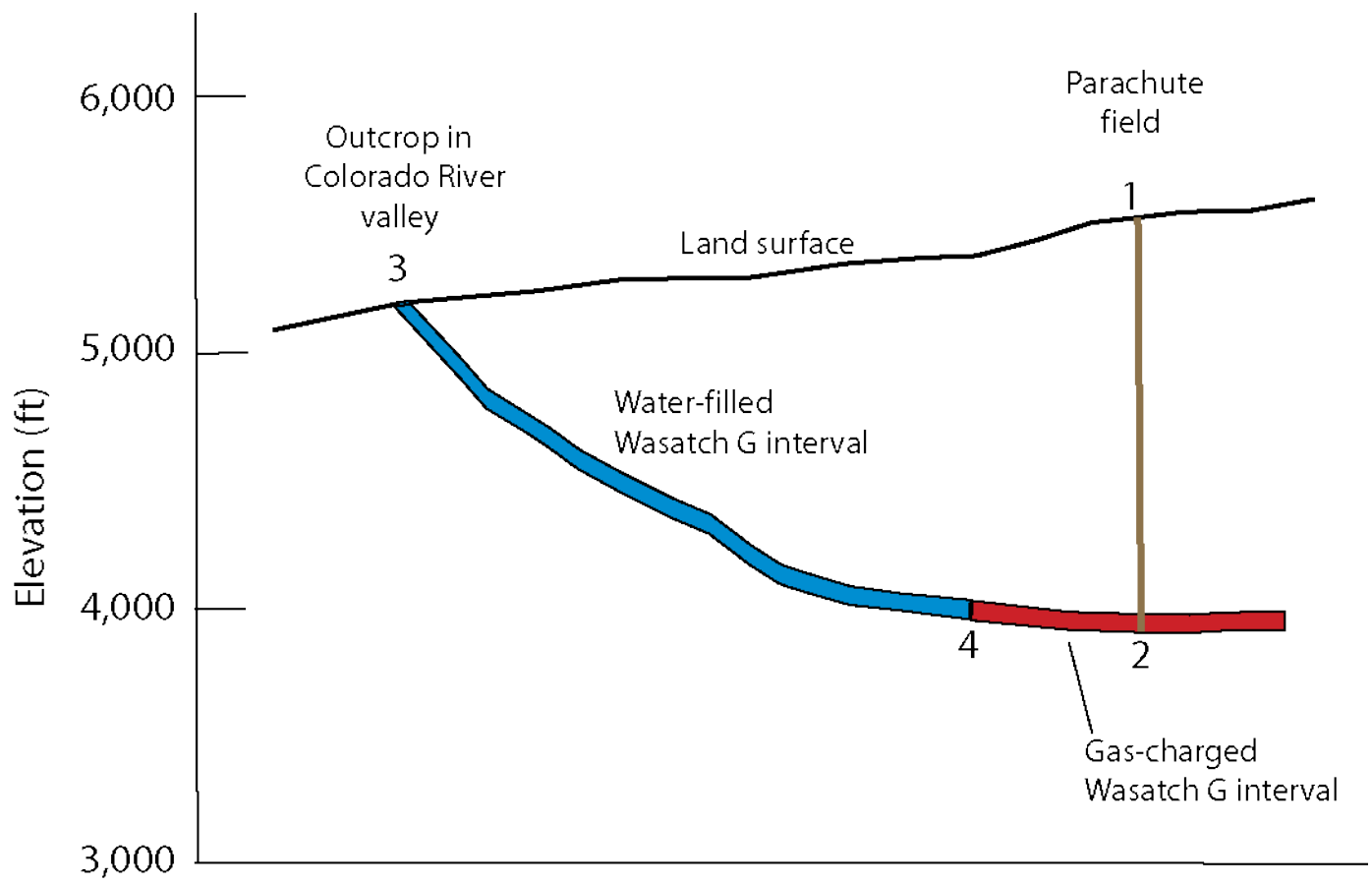

Figure 9. Schematic diagram of Wasatch $\mathrm{G}$ interval between outcrop in T. 8 S., R. 97 W. at 3 and gas reservoir in Parachute field at 2. Vertical scale is highly exaggerated, as distance between 3 and 1 is approximately $12 \mathrm{mi}$. See figure 1 for locations of outcrop and Parachute field. 
Table 3. Ratios of gas produced at the second sample to gas produced at first sample, presented as histograms and statistical summaries. Each X represents the ratio from one well. For example, for Grand Valley field, seven wells have ratios between 0.50 and 0.59 and the median value is 0.56 .

\begin{tabular}{lllll}
\hline \multicolumn{5}{c}{ Ratio of gas produced at second sample to gas produced at first sample } \\
\hline Range & $\begin{array}{l}\text { Grand Valley } \\
\text { field }\end{array}$ & $\begin{array}{l}\text { Parachute } \\
\text { field }\end{array}$ & Rulison field & $\begin{array}{l}\text { Mamm Creek } \\
\text { field }\end{array}$ \\
\hline $0.00-0.09$ & & $X$ & $X$ & \\
$0.10-0.19$ & & $X$ & XXX & \\
$0.20-0.29$ & XX & & XXX & XXXX \\
$0.30-0.39$ & XXX & $X$ & XXXXXXXXX & XXXX \\
$0.40-0.49$ & XXXX & XXX & XXXXXX & XX \\
$0.50-0.59$ & XXXXXXX & XXXXXX & XXXX & XXXXXXX \\
$0.60-0.69$ & XXXX & & XXX & XXXXX \\
$0.70-0.79$ & XXX & $X$ & & XX \\
$0.80-0.89$ & & XXXX & XX & XX \\
$0.90-0.99$ & $X$ & $X X$ & & $X$ \\
$1.00-1.09$ & $X$ & & & \\
$1.10-1.19$ & & $X$ & & $X X$ \\
$1.20-1.29$ & & & & \\
$1.30-1.39$ & & & $X$ & \\
$1.40-1.49$ & & & & \\
$1.50-1.59$ & $X$ & & 0.07 & 0.23 \\
& & & 1.43 & 1.33 \\
Minimum & 0.22 & 0.09 & 0.40 & 0.57 \\
Maximum & 1.52 & 1.19 & 0.45 & 0.61 \\
Median & 0.56 & 0.57 & 0.25 & 0.28 \\
Arithmetic mean & 0.58 & 0.62 & 32 & 30 \\
Standard deviation & 0.27 & 0.27 & & \\
Count & 27 & 20 & & \\
\hline
\end{tabular}




\section{Water and Gas Production from the Mesaverde Group}

The changes in water and gas in the Mesaverde Group between samples one and two, already summarized as change vectors on logarithmic plots on the plates, are also plotted using linear coordinates for the Grand Valley, Rulison, and Mamm Creek fields on figure 10. The plotting scheme of figure 10 is similar to that of figure $5 \mathrm{C}$, except the first point is not explicitly shown at 1,1 in figure 10 , and to avoid clutter, no vector is drawn from 1,1 to the second point. A well in which the water and gas production rates at the second sample are one-half that of the first sample would plot in the center of the lower left quadrant. Several features are noteworthy:

- All three fields have a significant number of wells that show increases in water production with time. However, more than half the wells (exactly half in Grand Valley field) show decreases in water production over the five years between the first and second samples, as shown by the median value for each of the fields.

- Each of the three fields has at least one well in which gas production increased over the five-year time span. It is likely that these increases were the result of a recompletion or some remedial action in the well.

- The median value of the reduction in gas production rates in the three fields is around 0.5 , as previously stated.

- The relation between water and gas decreases is strongest (scatter is least) in the Rulison field where water and gas production rates tend to decline at roughly the same rate. (If water and gas in each well declined at exactly the same rate, then all points would lie on a diagonal between 0,0 and 1,1.) Rulison field also has the greatest fraction of wells with water and gas declines of more than one half over the five-year time period.

- With the exception of Rulison field, the decline of water and gas does not exhibit much coherence, that is, the data for Grand Valley and Mamm Creek fields are scattered, not clustered, on the plots. 

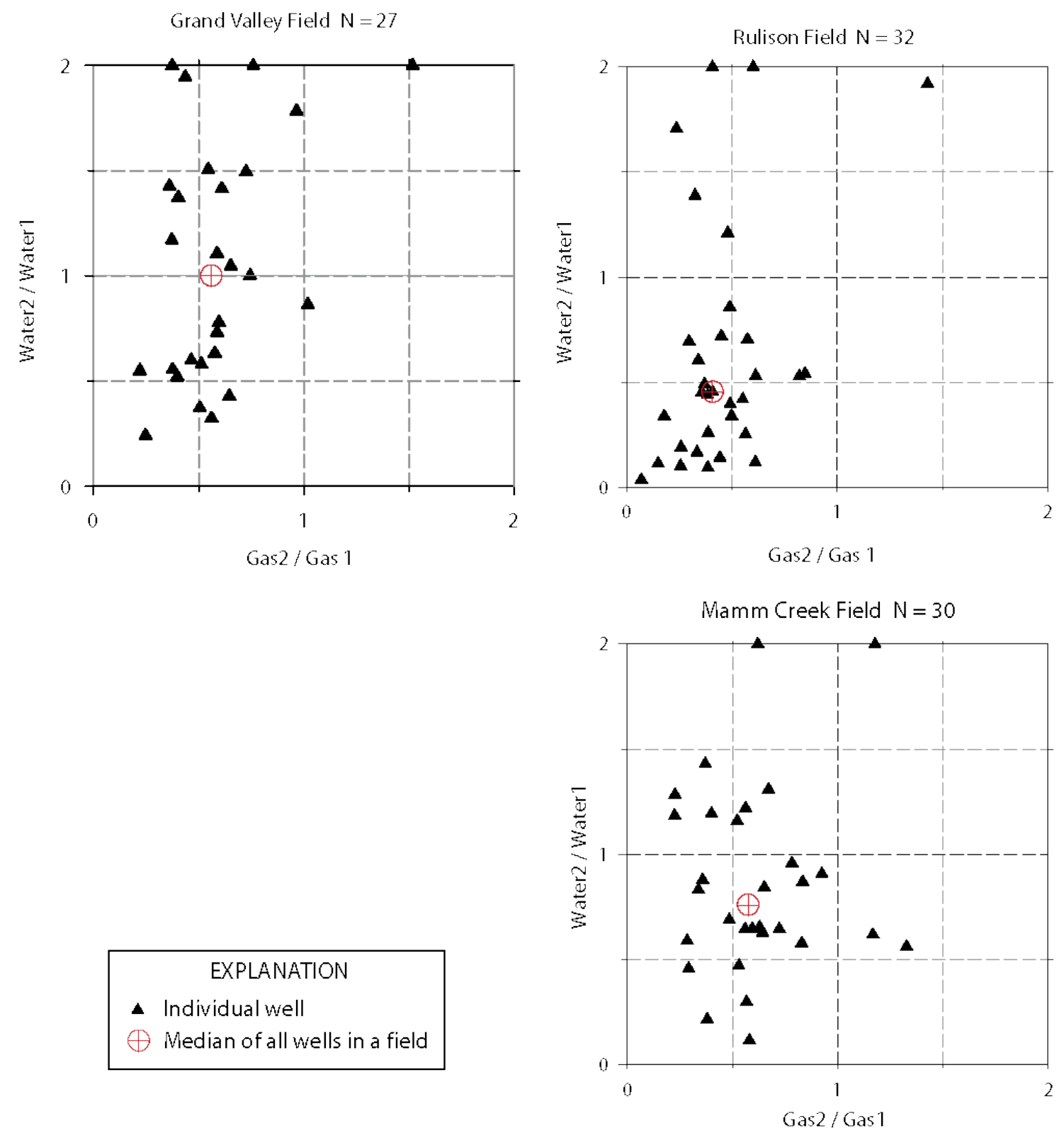

Figure 10. Ratio of water production rate at the second sample (Water2) to that of the first sample (Water1), plotted against the ratio of gas production rate at the second sample (Gas2) to the first sample (Gas1). Values of Water2/Water1 that exceed 2.0 are plotted at 2.0; there are three such points in Grand Valley field and two in Rulison field.

Median water-gas ratios at the first sample are 8.6, 7.0, 7.2, and $6.4 \mathrm{bbl} / \mathrm{mmcf}$ in Grand Valley, Parachute, Rulison, and Mamm Creek fields, respectively, and the lowest non-zero ratios are 2.3, 3.4, 2.1 , and $1.3 \mathrm{bbl} / \mathrm{mmcf}$ in the same fields. According to calculations, the amount of water dissolved in gas in the four fields producing from the Mesaverde Group is less than $1 \mathrm{bbl} / \mathrm{mmcf}$. (The calculations can be compared with the actual water-gas ratios in figures 3-2 of plate 3, 4-2 of plate 4, 5-2 of plate 5, and 6-2 of plate 6.) Thus, all wells exhibit water-gas ratios greater than the values calculated for water held in solution in the reservoir, with the implication that some free water is produced in all wells, although the amounts are low in many wells. 


\section{Lack of Dependence on Completion Parameters}

The tabulation of perforation data in appendixes 3-6 permits an inspection of production rates on (1) the depth extent of the perforated intervals, (2) the number of completion intervals, or (3) the number of perforations. However, graphical inspection of the first-sample gas rate, the decrease of gas with time, and first-sample water rate upon these three completion parameters showed no dependence in any of the four fields. One might expect gas and water production rates to increase with one or all three of these completion parameters, but such is not the case. Nor did the ratio of second-sample to firstsample gas show any marked dependence upon any of these measures of the amount of reservoir that was accessed. This lack of an obvious relationship between production and amount of exposed reservoir seems to reflect the difficulty in determining potential producing zones in low permeability reservoirs and the pervading state of the art of formation evaluation in the late 1990s.

\section{Summary}

Fluid production from the Wasatch $\mathrm{G}$ interval is characterized by the nearly complete absence of oil and water. The apparent underpressure in the Wasatch G gas fields - Parachute and Rulison-is attributed to hydraulic communication of the Wasatch $\mathrm{G}$ interval with the atmosphere where it crops out at the Colorado River, downstream from the Parachute field.

Gas production rates at the first and second samples are roughly normal in distribution, with the exception of Rulison-Mesaverde field, which has the most productive individual wells and a skewed distribution for first-sample gas production. In all fields, gas decline rates over the five-year span between the first and second samples are also normally distributed, with gas production at the second sample being roughly one-half that of the first sample. These statements hold for both the Wasatch G interval and the Mesaverde Group.

For fields producing from the Mesaverde Group, water production is generally unrelated to gas production, with the exception of Rulison field, where declines in gas production are roughly matched by declines in water production. Water-gas ratios exceed the amount expected to be in solution in the reservoir by factors of ten and more, indicating that substantial amounts of free water are produced along with the gas. There appears to be some spatial control on water production in Mamm Creek field, but not in Grand Valley or Rulison fields. Oil-gas ratios increase from west to east, although the reporting of oil is poor in Grand Valley and Parachute fields. Oil-gas ratios in the Mesaverde Group are all within the wet gas domain.

\section{Acknowledgments}

We benefitted from discussions with Mark Kirschbaum, Tom Finn, and Ron Johnson of the U.S. Geological Survey, and from reviews by Ron Charpentier of the U.S. Geological Survey and Steve Cumella of Bill Barrett Corporation.

\section{References Cited}

Brown, A., 2005, Effects of exhumation on gas saturation in tight gas sandstones, in Bishop, M.G., Cumella, S.P., Robinson, J.W., and Silverman, M.R., eds., Gas in low permeability reservoirs of the Rocky Mountain region: Denver, Colo., Rocky Mountain Association of Geologists 2005 Guidebook CDROM, p. 33-50. 
Carlstrom, G.M., 2003, Wasatch “G” sandstone-A conventional reservoir in a non-conventional basin, chap. 4 in Peterson, K.M., Olson, T.M., and Anderson, D.S., eds., Piceance Basin Guidebook:

Denver, Colo., Rocky Mountain Association of Geologists, p. 63-77.

Cole, R., and Cumella, S., 2003, Stratigraphic architecture and reservoir characteristics of the Mesaverde Group, southern Piceance Basin, Colorado, chap. 18 in Peterson, K.M., Olson, T.M., and Anderson, D.S., eds., Piceance Basin Guidebook: Denver, Colo., Rocky Mountain Association of Geologists, p. 385-442.

Cumella, S.P., and Ostby, D.B., 2003, Geology of the basin-centered gas accumulation, Piceance Basin, Colorado, chap. 10 in Peterson, K.M., Olson, T.M., and Anderson, D.S., eds., Piceance Basin Guidebook: Denver, Colo., Rocky Mountain Association of Geologists, p. 171-193.

Cumella, S.P., and Scheeval, J., 2008, The influence of stratigraphy and rock mechanics on Mesaverde gas distribution, Piceance Basin, Colorado, in Cumella, S.P., Shanley, K.W., and Camp, W.K., eds., Understanding, exploring, and developing tight-gas sands-2005 Vail Hedberg Conference: American Association of Petroleum Geologists, Hedberg Series, vol. 3, p. 137-155.

Donnell, J.R., 1969, Paleocene and lower Eocene units in the southern part of the Piceance Creek Basin, Colorado: U.S. Geological Survey Bulletin 1274-M, 18 p.

Hemborg, H.T., 1993, Wasatch Formation and Douglas Creek Member of the Green River Formation, in Hjellming, C.A., ed., Atlas of major Rocky Mountain reservoirs: Socorro, N. Mex., New Mexico Bureau of Mines and Mineral Resources, p. 96.

Hemborg, H.T., 2000, Gas production characteristics of the Rulison, Grand Valley, Mamm Creek, and Parachute Fields, Garfield County, Colorado-Turning marginally economic basin-centered tight-gas sands into profitable reservoirs in the southern Piceance Basin: Denver, Colorado Geological Survey Resource Series 39, 30 p.

Hoak, T.E., and Klawitter, A.L., 1997, Prediction of fractured reservoir production trends and compartmentalization using an integrated analysis of basement structures in the Piceance Basin, western Colorado, in Hoak, T.E., Klawitter, A.L., and Blomquist, P.K., eds., Fractured reservoirsCharacterization and modeling: Denver, Colo., Rocky Mountain Association of Geologists, p. 67102.

IHS Energy, 2009, U.S. production and well data: Englewood, Colo., IHS Energy [Database available from IHS Energy, 15 Inverness Way East, D205, Englewood, CO 80112, U.S.A.]

Johnson, R.C., 1989, Geologic history and hydrocarbon potential of Late Cretaceous-age, lowpermeability reservoirs, Piceance Basin, western Colorado: U.S. Geological Survey Bulletin 1787-E, $51 \mathrm{p}$.

Johnson, R.C. and Flores, R.M., 2003, History of the Piceance Basin from latest Cretaceous through early Eocene and the characterization of lower Tertiary sandstone reservoirs, chap. 3 in Peterson, K.M., Olson, T.M., and Anderson, D.S., eds., Piceance Basin Guidebook: Denver, Colo., Rocky Mountain Association of Geologists, p. 21-61.

Johnson, R.C., and Roberts, S.B., 2003, The Mesaverde Total Petroleum System, Uinta-Piceance Province, Utah and Colorado, chap. 7 of U.S. Geological Survey Uinta-Piceance assessment team, compilers, Petroleum systems and geologic assessment of oil and gas in the Uinta-Piceance Province, Utah and Colorado: U.S. Geological Survey Digital Data Series 69-B, 68 p. 
Lorenz, J.C., and Finley, S.J., 1991, Regional fractures II-Fracturing of Mesaverde reservoirs in the Piceance Basin, Colorado: American Association of Petroleum Geologists Bulletin, v. 75, no. 11, p. $1738-1757$.

Martinez, C., and Duey, H., 1982, Rulison field, in Crouch, M.C., III ed., Oil and gas fields of Colorado-Nebraska, and adjacent areas, v. II: Denver, Rocky Mountain Association of Geologists, p. 444-449.

McCain, W.D., Jr., 1990, The properties of petroleum fluids: Tulsa, Okla., Pennwell Books, 548 p.

Nelson, P.H., 2002, A review of the multiwell experiment in tight gas sandstones of the Mesaverde Group, Piceance Basin, Colorado: The Mountain Geologist, v. 39, no. 3, p. 53-71.

Nelson, P.H., and Hoffman, E.L., 2009, Gas, oil, and water production from the Wasatch Formation, Greater Natural Buttes Field, Uinta Basin, Utah: U.S. Geological Survey Open-File Report 20091049, 19 p.

Nelson, P.H., Trainor, P.K., and Finn, T.M., 2009a, Gas, oil, and water production in the Wind River Basin, Wyoming: U.S. Geological Survey Scientific Investigation Report 2008-5225, 24 pages with 8 plates.

Nelson, P.H., Ewald, S.M., Santus, S.L., and Trainor, P.K., 2009b, Gas, oil, and water production from the Jonah, Pinedale, Greater Wamsutter, and Stagecoach Draw Fields in the Greater Green River Basin, Wyoming: U.S. Geological Survey Open-File Report 2009-1290, 19 p.

Nuccio, V.F., and Roberts, L.N.R., 2003, Thermal maturity and oil and gas generation history of petroleum systems in the Uinta-Piceance Province, Utah and Colorado, chap. 4 in U.S. Geological Survey Uinta-Piceance assessment team, compilers, Petroleum systems and geologic assessment of oil and gas in the Uinta-Piceance Province, Utah and Colorado: U.S. Geological Survey Digital Data Series 69-B, $35 \mathrm{p}$.

Reinecke, K.M., Rice, D.D., and Johnson, R.C., 1991, Characteristics and development of fluvial sandstone and coalbed reservoirs of Upper Cretaceous Mesaverde Group, Grand Valley Field, Colorado in Schwochow, S.D., Murray, D.K., and Fahy, M.F., eds., Coalbed methane of western North America: Denver, Colo., Rocky Mountain Association of Geologists, p. 209-225.

Scott, R.B., and Shroba, R.R., 1997, Revised preliminary geologic map of the New Castle Quadrangle, Garfield County, Colorado: U.S. Geological Survey Open-File Report 97-737, 28 p., scale 1:24,000.

Shosa, J.D., and Cathles, L.M., 2001, Experimental investigation of capillary blockage of two phase flow in layered porous media, in Fillon, R.H., Rosen, N.C., and Weimer, P., eds., Petroleum systems of deep-water basins-Global and Gulf of Mexico experience, $21^{\text {st }}$ annual research conference, Houston, Tex., December 2-5, 2001, Proceedings: Gulf Coast Section-Society of Economic Paleontologists and Mineralogists Foundation, p. 725-739.

Shroba, R.R., and Scott, R.B., 1997, Geologic map of the Rifle quadrangle, Garfield County, Colorado: U. S. Geological Survey Open-File Report 97-852, 20 p., scale 1:24,000.

Shroba, R.R., and Scott, R.B., 2001, Geologic map of the Silt quadrangle, Garfield County, Colorado: U. S. Geological Survey Miscellaneous Field Studies Map MF-2331, 31 p., scale 1:24,000.

Warpinski, N.R., and Lorenz, J.C., 2008, Analysis of the multiwell experiment data and resultsImplications for the basin-centered gas model, in Cumella, S.P., Shanley, K.W., and Camp, W.K., 
eds., Understanding, exploring, and developing tight-gas sands-2005 Vail Hedberg Conference: Tulsa, Okla., American Association of Petroleum Geologists, Hedberg Series, vol. 3, p. 157-176.

Yurewicz, D.A., Bohacs, K.M., Kendall, J., Klimentidis, R.E., Kronmueller, K., Meurer, M.E., Ryan, T.C., and Yeakel, J.D., 2008, Controls on gas and water distribution, Mesaverde basin-centered gas play, Piceance Basin, Colorado, in Cumella, S.P., Shanley, K.W., and Camp, W.K., eds., Understanding, exploring, and developing tight-gas sands - 2005 Vail Hedberg Conference: Tulsa, Okla., American Association of Petroleum Geologists, Hedberg Series, vol. 3, p. 105-136. 